\title{
O żądaniach wpisu w polskim rejestrze stanu cywilnego zagranicznej fikcji prawnej pochodzenia dziecka od „rodziców jednopłciowych”
}

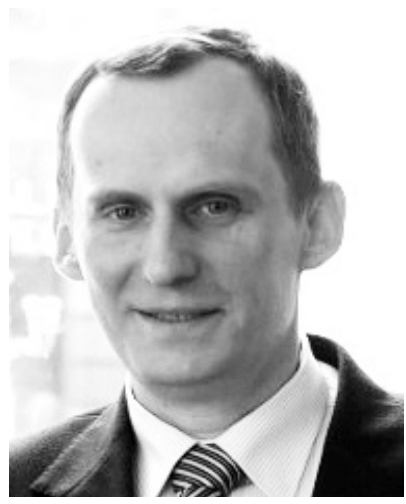

\section{Piotr Mostowik}

Profesor w Katedrze Prawa Prywatnego Międzynarodowego Uniwersytetu Jagiellońskiego w Krakowie, Instytut Wymiaru Sprawiedliwości $w$ Warszawie - Sekcja Praw Podstawowych.

$\triangle$ piotr.mostowik@uj.edu.pl

https://orcid.org/oooo-0003-3548-1003

\section{On Demands for Entry into Polish Birth Records of Foreign Legal Fiction of a Child's Origin from 'Same-Sex Parents'}

\begin{abstract}
Polish administrative courts were in 2018 requested to register in Polish birth records the child's origin from "same-sex parents" (de facto - homosexual couples). The author discusses the national legal provisions. In the matters of civil status in question there is no harmonization of law at the international level, and the European Union has no competence in the field of substantive personal and family law. Such issues and - being their reflexes - the registration of civil status (filiation or marriage) are subject to the internal legislation of each state. Legal systems differ manifestly in the world. The author emphasizes that there is no possibility of transferring to the domestic register of civil status (birth records) a foreign document incompatible with the fundamental principles of forum's law, which is justified in particular by the need to protect the effectiveness of the principles of the Polish ordre public, which are declared in the Constitution (Art. 18). They include i.a. the understanding of the principle of filiation or marital status, and the registration system should be compatible with the legal fundaments of the state. The proposed solution does not mean, however, that it is not possible to settle a detailed administrative case residing abroad, e.g. to obtain an identity card by the child living abroad. For the purpose of such separate administrative proceedings, a foreign document or a part of it may be treated as confirmation of the status of parents (i.e. a man and a woman who gave birth to a child) being Polish citizens.
\end{abstract}

Słowa kluczowe: prawo o aktach stanu cywilnego, akt urodzenia, klauzula porządku publicznego, prawo prywatne międzynarodowe, kolizja praw

Key words: civil status, birth records, order public clause, private international law, conflict of laws

https://doi.org/10.32082/fp.v6i56.206 


\section{Doniosłość krajowej rejestracji}

Kwestia zmiany krajowych założeń rejestracji stanu cywilnego wynikająca z żądania rejestracji urodzenia dziecka od „rodziców jednopłciowych” (w trybie transkrypcji za zawartością obcego dokumentu) była w ostatnim czasie przedmiotem interesujących rozważań sądów administracyjnych ${ }^{1}$. Obejmuje ona kategorie zasadnicze w prawie publicznym i prywatnym, jakimi są: pochodzenie człowieka, pokrewieństwo (filiacja), macierzyństwo i ojcostwo. Zaistniała w judykaturze wątpliwość dotycząca treści polskiego rejestru została przesądzona $\mathrm{w}$ - wyznaczającej kierunek przyszłego orzecznictwa - Uchwale składu siedmiu sędziów Naczelnego Sąd Administracyjny z 2 grudnia 2019 r. ${ }^{2}$ Interesujące dla doktryny są też wcześniejsze rozstrzygnięcia organów administracji i sądów oraz ich uzasadnienia, w tym rozbieżności w orzecznictwie zaistniałe w $2018 \mathrm{r}$. Celem poniższych uwag jest przedstawienie na tle tego orzecznictwa ogólniejszych problemów rejestracji stanu cywilnego w Polsce, też z perspektywy prawa konstytucyjnego, prawa rodzinnego i prawa prywatnego międzynarodowego, jak też kontekstu międzynarodowego.

Tytułem wstępu warto podkreślić, że skutki dokonania rejestracji w polskim rejestrze (tu: wytworzenia krajowego aktu urodzenia) są doniosłe nie tylko teoretycznie, ale i praktycznie. Zgodnie bowiem z art. 3 ustawy z dnia 28 listopada 2014 r. - Prawo o aktach stanu cywilnego ${ }^{3}$,akty stanu cywilnego stanowią wyłączny dowód zdarzeń w nich stwierdzonych; ich niezgodność z prawdą może być udowodniona jedynie w postępowaniu sądowym”. W doktrynie mówi się na jego tle o „preponderancji aktów stanu

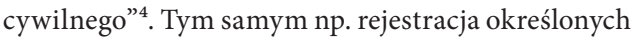

1 Problematykę dokumentów dotyczących stanu cywilnego w obrocie międzynarodowym, w tym dotychczasowe wypowiedzi piśmiennicze i orzecznicze, przedstawia P. Kasprzyk (red.), Podręcznik urzędnika stanu cywilnego, t. 2: Obrót prawny z zagranica $w$ zakresie rejestracji stanu cywilnego, Lublin 2019, s. 47-88.

2 Uchwała NSA z 2 grudnia 2019 r., II OPS 1/19; http://orzeczenia.nsa.gov.pl/doc/0CB4DBF3D4, 24.01.2020.

3 T.j. Dz.U. 2018 poz. 2224 ze zm. (dalej: p.a.s.c.).

4 Zob. J. Dobkowski, Preponderancja aktów stanu cywilnego, „Metryka” 2011, nr 2, s. 15-32, http://metryka.info/wp-content/uploads/2016/06/2_dobkowski.pdf, 24.01.2020. osób w akcie urodzenia dziecka jako jego rodziców wywołuje daleko idące konsekwencje w obrocie nie tylko publicznoprawnym (nie tylko w szczegółowej sprawie administracyjnej, w której załatwieniu pokrewieństwo jest przesłanką) i prywatnoprawnym ${ }^{5}$. Prawna problematyka pochodzenia dziecka, jak swoisty „awers", jest de facto tożsama ze - stanowiącym „rewers” - zagadnieniem rodzicielstwa (tj. macierzyństwa i ojcostwa).

Polska rejestracja stanu cywilnego, w tym urodzenia dziecka oraz osób o statusie matki i ojca, może być nie tylko pierwotna, ale - pod określonymi warunkami, o których będzie mowa poniżej - również pochodna od rejestracji zagranicznej. Możliwość swego rodzaju skopiowania zagranicznego wpisu przewidują art. $104 \mathrm{i}$ in. p.a.s.c., a wcześniej podobny stan normatywny w tej ogólnej kwestii wynikał z art. 73 i n. ustawy z 1986 r. ${ }^{6}$ oraz ustaw szczególnych ${ }^{7}$. Zgodnie z art. 104 p.a.s.c. „Zagraniczny dokument stanu cywilnego, będący dowodem zdarzenia i jego rejestracji, może zostać przeniesiony do rejestru stanu cywilnego $\mathrm{w}$ drodze transkrypcji”". Zagraniczna rejestracja dokonywana

5 Zob. A. Czajkowska (w:) I. Basior, A. Czajkowska, D. Sorbian (red.), Prawo o aktach stanu cywilnego z komentarzem. Przepisy wykonawcze i związkowe oraz wzory dokumentów, Warszawa 2015, s. 21 i n. Zob. też K. Michałowska, Niemajątkowe wartości życia rodzinnego w polskim prawie cywilnym, Warszawa 2017, s. 319 i n.

6 Ustawa z dnia 29 września 1986 r. Prawo o aktach stanu cywilnego, t.j. Dz.U. 2011 nr 212 poz. 1264 ze zm.

7 Zob. P. Wypych, Charakter prawny transkrypcji aktu stanu cywilnego sporzadzonego za granica, „Kwartalnik Prawa Prywatnego" 2003, nr 1, s. 189 i n.

8 Wojewódzki Sąd Apelacyjny w Krakowie w uzasadnieniu Wyroku z dnia 10 maja 2016 r. (III SA/Kr 1400/15, http:// orzeczenia.nsa.gov.pl/doc/431B8D990D, 24.01.2020) trafnie podkreślił, że „W wyniku transkrypcji powstaje polski akt stanu cywilnego, który nie różni się treścią od aktu transkrybowanego, a pod względem formy, mocy dowodowej oraz zasad korekty, nie różni się od aktów stanu cywilnego rejestrujących zdarzenia krajowe (tak też: postanowienie Sądu Najwyższego z dnia 16 marca 2007 r., III CSK 380/06 opubl. LEX 457689, wyrok Wojewódzkiego Sądu Administracyjnego w Warszawie z dnia 1 kwietnia 2010 r., IV SA/ Wa 270/10 - opubl. LEX 620136, postanowienie SN z dnia 3 czerwca 2011 r., III CSK 259/10 - opubl. LEX 1129120)". 
jest z istoty wcześniej na podstawie obcego prawa proceduralnego i materialnego (a dokładniej - na podstawie prawa rodzinnego, które zostaje wskazane jako właściwe normami kolizyjnymi w państwie rejestracji) ${ }^{9}$.

Żądania transkrypcji w trybie art. 104 i in. p.a.s.c. zagranicznego dokumentu, w którym jako rodzice dziecka zamiast matki i ojca widnieją dwie osoby tej samej płci (w praktyce - pary homoseksualne), tj. stworzenie krajowego aktu urodzenia o takiej powielonej treści, były przedmiotem kilku postępowań sądowoadministracyjnych. $Z$ uwagi na powiązania faktyczne (sytuacji życiowych) i powiązanie kwestii prawnych orzecznictwo trzeba oceniać łącznie z rozstrzygnięciami w sprawach o wydanie dowodu tożsamości ${ }^{10}$ albo stwierdzenie obywatelstwa dziecka obywatela polskiego, który w zagranicznym akcie widnieje jako jeden $\mathrm{z}$ „,rodziców jednopłciowych”.

Na marginesie można zauważyć, że w omawianym czasie Rzecznik Praw Obywatelskich nie tylko angażował się na rzecz niektórych stron postępowań, ale zwrócił się nawet do Ministra Spraw Wewnętrznych o zmianę rozporządzeń wykonawczych i zmianę obecnego sposobu sporządzenia aktów urodzeń przez odejście od rejestracji pochodzenia dziecka od matki będącej kobietą i ojca będącego mężczyzną ${ }^{11}$. Wniosek ten nie znajdował oparcia w większości wyroków wyda-

9 Zob. M. Wojewoda, Kolizyjnoprawne aspekty rejestracji stanu cywilnego (w:) M. Pazdan (red.), System Prawa Prywatnego, t. 20C: Prawo prywatne międzynarodowe, Warszawa 2015 , s. 535 i n., tenże, Transkrypcja aktu urodzenia dziecka, które zostało uznane za granica, „Kwartalnik Prawa Prywatnego” 2017, nr 2, s. 347-350.

$10 \mathrm{Tj}$. postępowaniami w sprawach szczegółowych względem postępowania o transkrypcję: o wydanie dowodu osobistego lub nadanie numeru PESEL (art. 5 Ustawy $z$ dnia 6 sierpnia 2010 r. o dowodach osobistych; t.j. Dz.U. 2017 poz. 1464 ze zm.) bądź o wydanie paszportu obywatelowi polskiemu (art. 3 Ustawy z dnia 13 lipca 2006 r. o dokumentach paszportowych; t.j. Dz.U. 2018 poz. 1919).

11 Zob. wystąpienie z 11 marca 2019 r. do Ministra Spraw Wewnętrznych o „udzielenie informacji, czy planowana jest zmiana przepisów rozporządzenia (...) w sprawie wzorów dokumentów wydawanych z zakresu rejestracji stanu cywilnego, tak aby wzór formularza - 4 - aktu urodzenia umożliwiał transkrypcję zagranicznego aktu urodzenia dziecka pary jednopłciowej"; www.rpo.gov.pl/pl/content/ wanych przez sądy administracyjne w ostatnich latach, a obecnie nie ma już żadnego uzasadnienia z orzecznictwa, w którym rozbieżności zostały przesądzone uchwałą wydaną w poszerzonym składzie. Podobne żądanie może zostać ponowione jako postulat de lege ferenda bądź jako kierunek wykładni postulowany trybunałom międzynarodowym, stąd poniższe uwagi mogą być przydatne również w przyszłym dyskursie.

\section{2. Żądania rejestracji „rodziców jednopłciowych" w polskich aktach urodzenia na tle orzecznictwa sądowoadmistracyjnego}

\subsection{Linia orzecznicza}

Istotne znaczenie dla rozumienia w Polsce istoty stanu cywilnego i zakresu jego rejestracji ma - sygnalizowana na wstępie - Uchwała siedmiu sędziów NSA z 2 grudnia 2019 r., jak też wcześniejsze wyroki NSA: z dnia 20 czerwca 2018 r. $^{12}$, z dnia 10 października 2018 r. $^{13}$ i z dnia 30 listopada 2018 r. $^{14}$, oraz wyrok Wojewódzkiego Sądu Administracyjnego w Poznaniu z dnia 5 kwietnia 2018 r. ${ }^{15}$ Wzięcia pod uwage wymaga także - niezauważona w kluczowym dla przyszłej praktyki wyroku NSA z 10 października 2018 r. - uchwała Izby Cywilnej Sądu Najwyższego $\mathrm{z}$ dnia 20 listopada $2012 \mathrm{r}^{16}$

problemy-z-wykonaniem-wyroku-nsa-o-wpisie-do-akt-stanu-cywilnego-rodzicow-tej-samej-p\%C5\%82ci, 31.12.2019.

12 Wyrok NSA z 20 czerwca 2018 r., II OSK 1808/16, LEX nr 2513922, http://orzeczenia.nsa.gov.pl/doc/F1FEC11C03, 24.01.2020; dalej: Wyrok NSA z 20 czerwca 2018 r.

13 Wyrok NSA z 10 października 2018 r., II OSK 2552/16, http:// orzeczenia.nsa.gov.pl/doc/013EB55F39, 24.01.2020; dalej: Wyrok NSA z 10 października $2018 \mathrm{r}$.

14 Wyrok NSA z 30 października 2018 r., II OSK 1868/16, http://www.orzeczenia-nsa.pl/wyrok/ii-osk-1868-16/ obywatelstwo/293ac30.html, 24.01.2020; dalej: Wyrok NSA z 30 października $2018 \mathrm{r}$.

15 Wyrok WSA w Poznaniu z 5 września 2018 r., II SA/Po 1169/17, http://orzeczenia.nsa.gov.pl/doc/7C7192478E, 24.01.2020; dalej: Wyrok WSA w Poznaniu z 5 września 2018 r.

16 III CZP 58/12, www.sn.pl/Sites/orzecznictwo/Orzeczenia2/ III\%20CZP\%2058-12.pdf, 24.01.2020; dalej: Uchwała SN z 20 listopada 2012 r. 
Skargi do sądów administracyjnych w postępowaniach zakończonych wyrokami NSA z 20 czerwca 2018 r., 10 października 2018 r. oraz postępowaniu, w którym zwrócono się o uchwałę poszerzonego składu NSA, dotyczyły odmowy przez kierowników urzędów stanu cywilnego oraz wojewodów wnioskowanej rejestracji „urodzenia od osób tej samej płci”, która miała powielać fikcje prawne przewidziane
WSA w Krakowie. Wyrok ten, jak również wyrok WSA w Poznaniu z dnia 5 kwietnia 2018 r., wywołały w 2018 r. niejednolitość orzecznictwa ${ }^{19}$.

Ponieważ w kontekście takich ogólnych postępowań o transkrypcję widzieć trzeba inne postępowania administracyjne, które dotyczą spraw szczegółowych powiązanych (a przynajmniej potencjalnie powiązanych w praktyce $\mathrm{z}$ uwagi na taką deklarację stron co

\section{Do 2018 r. organy i sądy administracyjne} konsekwentnie jednolicie odmawiały przerejestrowywania w trybie transkrypcji w polskim akcie urodzenia dwóch osób tej samej płci jako „matki” i „ojca”.

w niektórych prawach obcych. Odmowa była uzasadniona niemożnością przeniesienia zagranicznej rejestracji z uwagi na podstawowe zasady polskiego prawa o aktach stanu cywilnego oraz prawa osobowego i rodzinnego (art. 103 p.a.s.c.).

Do 2018 r. organy i sądy administracyjne konsekwentnie jednolicie odmawiały przerejestrowywania w trybie transkrypcji w polskim akcie urodzenia dwóch osób tej samej płci jako „matki” i „ojca”"17. Tytułem przykładu można wskazać wyrok NSA z 20 czerwca 2018 r., a także wcześniejszy wyrok NSA z 17 grudnia 2014 r. $^{18}$ Stąd zaskoczeniem, o czym niżej, mogła być sentencja, a w szczególności uzasadnienie wyroku NSA z 10 października 2018 r. Mocą tego ostatniego uchylono decyzje kierownika Urzędu Stanu Cywilnego w Krakowie i Wojewody Małopolskiego o odmowie transkrypcji i podtrzymujący je wyrok

17 Zob. E. Przyśliwska-Urbanek, Aktualne orzecznictwo sądów administracyjnych dotyczace rejestracji pochodzenia dziecka od osób tej samej ptci (w:) J. Gołaczyński, W. Popiołek (red.), Kolizyjne i procesowe aspekty prawa rodzinnego, Warszawa 2019, s. 151-160.

18 Wyrok NSA z 17 grudnia 2014 r., II OSK 1298/13, http:// orzeczenia.nsa.gov.pl/doc/ADA943DFA1, 24.01.2020. do wykorzystania transkrybowanego w Polsce aktu, np. w sprawie wydania dowodu tożsamości dziecka). Spośród nich należy wziąć pod uwagę wyrok NSA z 30 listopada 2018 r., który zapadł w sprawie o wydanie dziecku polskiego dowodu tożsamości. Konieczne jest przy tym rozróżnienie ogólnych spraw o transkrypcję zagranicznej treści do polskiego rejestru oraz innych spraw szczegółowych potencjalnie z nimi w praktyce powiązanych, tj. np. o stwierdzenie obywatelstwa ${ }^{20}$, nadanie numeru PESEL lub wydanie dowodu tożsamości, o czym niżej. Trzeba też mieć na względzie, że - mimo iż wszystkie te sprawy rozpoznawane są przez organy i sądy administracyjne - to dla ich oceny istotne znaczenie mają

19 Stanowisko odmienne od dotychczasowego orzecznictwa wyrażono też w Wyroku WSA z 5 kwietnia 2018 r. w sprawie, która jest obecnie rozpoznawana przez NSA w postępowaniu kasacyjnym.

20 Na podstawie art. 6 ust. 1 Ustawy z dnia 2 kwietnia 2009 r. o obywatelstwie polskim (t.j. Dz.U. 2018 poz. 1829, dalej: u.obyw.pol.). Zob. P. Mostowik, Problem obywatelstwa dziecka prawdopodobnie pochodzacego od obywatela polskiego niebędącego mężem surrogate mother. Uwagi aprobujące wyroki NSA z 6 maja 2015 r. (II OSK 2372/13 I II OSK 2419/13), „Problemy Współczesnego Prawa Międzynarodowego, Europejskiego i Porównawczego" 2018, t. 16, s. 55 i n. 
nie tylko przepisy materialnego i procesowego prawa administracyjnego, ale również przepisy prawa rodzinnego i prawa prywatnego międzynarodowego ${ }^{21}$.

\subsection{Wyłom w orzecznictwie}

W sprawie rozpoznanej wyrokiem NSA z 10 października 2018 r. organy administracji wydały decyzje i wyrok, które odmawiały spełnienia żądania przeniesienia do polskich aktów stanu cywilnego z zagranicznego rejestru danych dwóch osób tej samej płci jako „rodziców”. Kierownik USC w Krakowie, Wojewoda Małopolski i WSA w Krakowie wskazali, że w świetle art. 55 Prawa prywatnego międzynarodowego ${ }^{22}$ ustalenie pochodzenia dziecka podlega prawu ojczystemu dziecka z chwili jego urodzenia. Prawo polskie określa między innymi, kto w jego rozumieniu jest matką i ojcem, a także że rodzice to osoby różnej płci (tj. za prawdę biologiczną i genetyczną przyjmuje, że dziecko pochodzi od kobiety i mężczyzny). Z prawa polskiego nie wynika, że pierwotną matką może być kobieta inna niż ta, która dziecko urodziła, ani że drugim z rodziców w znaczeniu prawnym może być osoba tej samej płci ${ }^{23}$. Podstawową zasadą prawa polskiego, wyrażoną w art. 61[9] Kodeksu rodzinnego i opiekuńczego z dnia 25 lutego $1964 \mathrm{r}^{24}$, jest macierzyństwo (pochodzenie dziecka) kobiety, która dziecko urodziła. Natomiast niezależnie od sposobu ustalenia ojcostwa - drugim z rodziców prócz matki, tj. ojcem dziecka, jest zgodnie z polskim prawem mężczyzna. Również w rozumieniu p.a.s.c. rodzicami są zawsze matka i ojciec. Z tych względów wpisanie do polskiego aktu urodzenia dru-

21 Zob. P. Mostowik, Pochodzenie dziecka (w:) M. Pazdan (red.), System Prawa Prywatnego, dz. cyt., s. 308 i n.

22 Ustawa z dnia 4 lutego 2011 r. Prawo prywatne międzynarodowe, t.j. Dz.U. 2015 poz. 1792; dalej: p.p.m. Na temat wyznaczenia prawa właściwego, któremu w polskim obrocie podlega stosunek macierzyństwa i ojcostwa - zob. P. Mostowik, $W$ ładza rodzicielska w prawie prywatnym międzynarodowym, Kraków 2014, s. 27 i n., http://www.bibliotekacyfrowa. $\mathrm{pl} / \mathrm{dlibra} /$ publication/63950/edition/63839? language $=\mathrm{pl}$, 24.01.2020; tenże (w:) M. Pazdan (red.), System Prawa Prywatnego, dz. cyt., s. 308 i n.

$23 \mathrm{Na}$ temat kluczowych rozwiązań polskiego prawa filiacyjnego - zob. T. Smyczyński (red.), System Prawa Prywatnego, t. 12: Prawo rodzinne i opiekuńcze, Warszawa 2011, s. 25-27. 24 T.j. Dz.U. 2017 poz. 682 ze zm.; dalej: k.r.o. giej kobiety (co dotyczy też drugiego mężczyzny) jako ojca dziecka, a nie mężczyzny (matki), stanowiłoby nie tylko naruszenie obowiązującego w Polsce porządku prawnego, ale także wprowadzałoby w błąd. WSA w Krakowie w wyroku z 10 maja 2016 r. zauważył przy tym, że „sądy administracyjne związane są obowiązującymi przepisami prawa, tj. Konstytucją RP i ustawami, których konstytucyjności jednakże badać nie mogą. Poza kognicją sądów leżą też funkcje prawotwórcze".

Naczelny Sąd Administracyjny wyrokiem z 10 października 2018 r. uchylił powyższe decyzje i wyrok WSA w Krakowie. To orzeczenie może, choć nie musi - z uwagi na zasadnicze wątpliwości co do jego uzasadnienia na tle dotychczasowego orzecznictwa, w tym wyroku NSA z 20 czerwca 2018 r., oraz na nieco zmieniony kontekst normatywny po jego wydaniu w związku z wyrokiem NSA z 30 listopada 2018 r., o czym niżej - prowadzić też do utrzymania w mocy przez NSA wyroku WSA w Poznaniu, a w konsekwencji do zmiany linii orzeczniczej w sprawach rejestracji w polskich aktach stanu cywilnego pochodzenia dziecka od „rodziców jednopłciowych”. W dalszej perspektywie może to doprowadzić do sporządzania polskich aktów urodzenia, z których wynikać będzie, że dziecko pochodzi od "matki” i „ojca” będących osobami tej samej płci, co z kolei mieć będzie daleko idące skutki dla wszystkich gałęzi prawa z uwagi na dalekosiężne skutki rejestracji (art. 3 p.a.s.c.).

Trzeba od razu zauważyć, że skutki aktu stanu cywilnego - w tym tego, który może powstać w razie uchylenia dotychczasowej linii orzeczniczej kierowników urzędu stanu cywilnego, są generalnie daleko idące dla całego obrotu prawnego, w tym osób trzecich. Warto mieć w szczególności na względzie, że akt stanu cywilnego, w tym transkrybowany, zgodnie $\mathrm{z}$ art. 3 p.a.s.c. stanowi wyłączny dowód zdarzeń w nim stwierdzonych, a jego niezgodność z prawdą może być udowodniona jedynie w postępowaniu sądowym. Między innymi z tego powodu wyrok NSA z 10 października 2018 r. oraz tezy zawarte w jego uzasadnieniu rodzić mogą uwagi polemiczne.

\subsection{Uchwała siedmiu sędziów NSA z 2 grudnia $2019 r$.}

Naczelny Sąd Administracyjny w poszerzonym składzie odpowiadał na pytanie, zadanie przez skład NSA rozpoznający kolejną podobną sprawę. Skład siedmiu 
sędziów NSA przyjął uchwałę mówiącą, że „art. 104 ust. 5 i art. 107 pkt 3 p.a.s.c w zw. z art. 7 p.p.m. nie dopuszcza transkrypcji zagranicznego aktu urodzenia dziecka, w którym jako rodzice wpisane są osoby tej samej płci”. Nie jest możliwe wpisanie w polskim akcie stanu cywilnego zamiast ojca dziecka „rodzica”, który nie jest mężczyzną, gdyż taka transkrypcja byłaby sprzeczna z podstawowymi zasadami polskiego porządku prawnego. o dokumentach paszportowych ${ }^{25}$ (a tym samym brak jest potrzeby ubiegania się o transkrypcję). Natomiast odnośnie do spraw o wydanie dowodu osobistego oraz nadanie numeru PESEL podkreślono, że są one przedmiotem rozstrzygnięć wydawanych w osobnych postępowaniach oraz zaskarżalnych. Zauważono przy tym, że przyjęta w uchwale z 2 grudnia 2019 r. wykładania art. 104 ust. 5 p.a.s.c. nie może prowadzić do uzależnienia uzyskania przez obywatela polskiego dowodu

\section{Skład siedmiu sędziów NSA przyjął uchwałę} mówiącą, że „art. 104 ust. 5 i art. 107 pkt 3 p.a.s.c w Zw. $z$ art. 7 p.p.m. nie dopuszcza transkrypcji zagranicznego aktu urodzenia dziecka, w którym jako rodzice wpisane są osoby tej samej płci”.

Sąd podkreślił przy tym, że obligatoryjność, o której mowa w art. 104 ust. 5 p.a.s.c. (tj. sytuacja, w której polski obywatel posiada akt sporządzony na terytorium Polski i żąda dokonania czynności z zakresu rejestracji stanu cywilnego lub ubiega się o polski dokument tożsamości lub nadanie numeru PESEL), nie wyłącza stosowania przesłanek transkrypcji określonych w art. 107 p.a.s.c. Odmowa powinna mieć miejsce w razie sprzeczności z podstawowymi zasadami prawa forum, co jest konieczne dla eliminacji niespójności systemu, która by wystąpiła, jeżeliby funkcjonowały krajowe akty urodzenia $\mathrm{z}$ danymi niepodlegającymi zasadniczo rejestracji w Polsce.

Od razu trzeba zauważyć, że Sąd zauważył doniosłość w praktyce powiązania ogólnego postępowania o transkrypcję z innymi szczegółowymi postępowaniami administracyjnymi. W uzasadnieniu uchwały NSA z 2 grudnia 2019 r. zauważono przy tym, że co prawda wniosek o wydanie dokumentu paszportowego powinien zawierać numer PESEL, ale konsul może wydać małoletniemu obywatelowi polskiemu urodzonemu za granicą paszport tymczasowy bez zamieszczania w nim tego numeru art. 24 ust. 1 pkt 1 Ustawy tożsamości albo numeru PESEL od dokonania przez organ transkrypcji, która nie jest możliwa tylko z tego powodu, że w zagranicznym akcie urodzenia dziecka podano zamiast danych ojca dane kobiety, która pozostaje $\mathrm{w}$ nieznanym polskiemu prawu związku partnerskim z matką dziecka będącą obywatelką polską.

\section{Kluczowe problemy}

prawne w omawianym

orzecznictwie administracyjnym

i sadowoadministracyjnym

Zasadnicza linia orzecznicza sądów administracyjnych, w tym Uchwała siedmiu sędziów NSA z 2 grudnia 2019 r., pozwala na poczynienie uwag ogólniejszych, jak też wskazanie dodatkowych argumentów za wydanymi rozstrzygnięciami. Jedynie rozumowanie zaprezentowane w uzasadnieniu wyroku NSA z 10 października 2018 r. zasługuje na uwagi krytyczne - zarówno z perspektyw de lege lata oraz de lege ferenda, jak i z uwagi na aktywizm interpretacyjny w wymiarze

25 Ustawa z dnia 13 lipca 2006 r. o dokumentach paszportowych, t.j. Dz.U. 2018 poz. 1919. 
nieproporcjonalnym dla osiągnięcia deklarowanego celu. Nie można bowiem burzyć ogólnych zasad rejestracji stanu cywilnego, dotyczących wszystkich osób, celem pozytywnego załatwienia kazuistycznej sprawy dziecka polskiego obywatela zamieszkałego w państwie o innej kulturze prawnej.

\subsection{Potrzeba rozróżnienia postępowania}

o stworzenie polskiego aktu od wymagań dowodowych w postępowaniu o wydanie dowodu tożsamości

NSA w uchwale z 2 grudnia 2019 r. celnie zauważył, że na tle całości stanu faktycznego związanego z dzieckiem polskiego obywatela rodzą się dwie kategorie spraw administracyjnych, a nie tylko postępowanie o transkrypcję. Trudno zgodzić się natomiast z tezą zawartą w uzasadnieniu wyroku NSA z 10 paździer- uzasadnienie kontrolowanego wyroku WSA w Krakowie z 10 maja 2016 r. ${ }^{27}$, mówiące, że: „Sąd podkreśla, że o ile - jak wskazuje to Rzecznik Praw Obywatelskich - przepis art. 104 ust. 5 Prawa o aktach stanu cywilnego wprowadza obowiązek transkrypcji aktu urodzenia osoby, która ubiega się o polski dokument tożsamości - polski dokument paszportowy lub polski dowód osobisty, a dokumenty te są jedynymi przysługującymi obywatelowi polskiemu dokumentami, które poświadczają jego tożsamość i posiadanie polskiego obywatelstwa, to taki przepis mógłby rodzić wątpliwości co do jego zgodności z Konstytucją $\mathrm{RP}$, nie mniej niniejsza sprawa nie dotyczy wydania polskiego dokumentu paszportowego ani polskiego dowodu osobistego, a zatem zarzut Rzecznik Praw Obywatelskich w tym zakresie wykracza poza ramy rozpoznawanej sprawy”. Trafne było w szczególności

\section{NSA w uchwale z 2 grudnia 2019 r. celnie} zauważył, że na tle całości stanu faktycznego związanego z dzieckiem polskiego obywatela rodzą się dwie kategorie spraw administracyjnych, a nie tylko postępowanie o transkrypcję.

nika 2018 r. mówiącą, że od transkrypcji całego zagranicznego aktu, w którym „rodzice to dwie osoby tej samej płci”, zależy (a co najmniej - musi zależeć) to, że dziecko obywatela polskiego uzyska np. dowód osobisty jako polski obywatel ${ }^{26}$. Poprawniejsze wydaje się

26 Nie przekonuje w szczególności twierdzenie, że: „W aktualnym stanie prawnym dokumentami potwierdzającymi obywatelstwo polskie są paszport i dowód osobisty, a warunkiem wydania polskiego dokumentu tożsamości jest przedłożenie właściwemu organowi administracji polskiego aktu urodzenia. I ten aspekt sprawy, dotyczący obowiązkowej transkrypcji zagranicznego aktu urodzenia obywatela Rzeczypospolitej Polskiej, w ocenie Naczelnego Sądu Administracyjnego, a wbrew stanowisku WSA w Krakowie, jest kluczowy”. spostrzeżenie o niepokrywaniu się zakresów spraw, a tym samym o pomieszaniu w stanowisku Rzecznika Praw Obywatelskich argumentów dotyczących ogólnego postępowania o transkrypcję ze szczególnym postępowaniem o wydanie dowodu tożsamości. Rozpoznana wyrokiem NSA z 10 października 2018 r. sprawa nie dotyczyła wydania polskiego dowodu tożsamości, a zatem zarzuty w tym zakresie po prostu wykraczały poza formalne i materialne ramy rozpoznawanej sprawy.

Przede wszystkim trzeba mieć na względzie, że problem z udowodnieniem przez obywatela polskiego jego

27 Wyrok WSA w Krakowie z 10 maja 2016 r., III SA/Kr 1400/15, http://orzeczenia.nsa.gov.pl/doc/431B8D990D. 
macierzyństwa albo ojcostwa wynika z wymagania dowodowego w zupełnie innym postępowaniu administracyjnym (np. o stwierdzenie obywatelstwa lub o wydanie dowodu tożsamości), a nie - innym - postępowaniu o transkrypcję, o którym wypowiedział się Sąd. Z art. 104 ust. 5 p.a.s.c. wynika wymaganie dowodowe w innym postępowaniu, podwyższone względem treści art. 1138 Kodeksu postępowania cywilnego ${ }^{28}$ przyjętej w uchwale SN z 20 listopada 2012 r. (tj. możliwości posłużenia się w Polsce dla celów dowodowych zagranicznym dokumentem). Trudno natomiast ten przepis rozumieć jako bezwzględny obowiązek kierow-

\subsection{Brak możliwości pominięcia przy orzekaniu} podstawowych zasad krajowego prawa osobowego i rodzinnego

W uzasadnieniu wyroku z 10 października $2018 \mathrm{r}$. NSA nie zauważono wynikającej z prawa polskiego możliwości posłużenia się zagranicznym dokumentem stanu cywilnego (co by można odnieść też do jego części, np. dotyczącej polskiej obywatelki - kobiety, która dziecko urodziła i której prawny status macierzyństwa jest zgodny z podstawowymi zasadami polskiego prawa). W uchwale Izby Cywilnej Sądu Najwyższego z 20 listopada 2012 r. $^{29}$ stwierdzono, że

\section{Problem z udowodnieniem przez obywatela} polskiego jego macierzyństwa albo ojcostwa wynika $z$ wymagania dowodowego $w$ zupełnie innym postępowaniu administracyjnym.

nika urzędu stanu cywilnego „przerejestrowania” treści zagranicznego dokumentu nazwanego z określeniem „stan cywilny” z porzuceniem podstawowych zasad polskiego rejestru stanu cywilnego i prawa rodzinnego. Tym trudniej byłoby taki bezwzględny obowiązek uzasadniać tym, że wnioskodawca na potrzeby ogólnego postępowania o transkrypcję oświadcza, że w przyszłości będzie potrzebował posłużyć się tak pozyskanym aktem w osobnym postępowaniu o wydanie dowodu tożsamości.

Stąd bardziej przekonujące jest uzasadnienie uchwały NSA z 2 grudnia 2019 r., w którym zauważono, że każdy obywatel ma prawo do dowodu osobistego, a sądowej kontroli podlega zarówno odmowa, jak i bezczynność organu. To w tych postępowaniach można podnieść potrzebę rozwiązania problemu braku możliwości transkrypcji. Celne jest też spostrzeżenie, że w przepisach szczegółowych o nadaniu numeru PESEL nie ma przeciwwskazań do podania danych zagranicznego aktu stanu cywilnego.

28 Ustawa z dnia 17 listopada $1964 \mathrm{r}$. Kodeks postępowania cywilnego, t.j. Dz.U. 2018 poz. 1360 ze zm.; dalej: k.p.c. „akt stanu cywilnego sporządzony za granicą stanowi wyłączny dowód zdarzeń w nim stwierdzonych także wtedy, gdy nie został wpisany do polskich ksiąg stanu cywilnego", a uchwałę tę in extenso przytaczał wcześniej NSA w podobnych sprawach jako uzasadnienie odmiennego rozstrzygnięcia (w tym w uzasadnieniu wyroku NSA z 20 czerwca 2018 r.) oraz WSA w Krakowie w uzasadnieniu kontrolowanego przez NSA orzeczenia z dnia 10 maja 2016 r. ${ }^{30}$ Również w uza-

29 III CZP 58/12, www.sn.pl/Sites/orzecznictwo/Orzeczenia2/ III\%20CZP\%2058-12.pdf, 24.01.2020; dalej: Uchwała SN z 20 listopada 2012 r.

30 „Za nieuzasadniony należy uznać zarzut, jakoby odmowa dokonania transkrypcji miała uniemożliwić małoletniemu A. skutecznie wykazać i ustalić przed polskimi organami i sądami podstawowego elementu swojej tożsamości w postaci relacji z jednym ze swoich rodziców. W tym względzie należy mieć bowiem na uwadze przepis art. 1138 k.p.c., który przyznaje zagranicznym dokumentom urzędowym moc dowodową na równi z polskimi dokumentami urzędowymi, nie wprowadzając w tym zakresie jakichkolwiek dodatkowych wymogów, w szczególności w postaci transkrypcji tych dokumentów. Niezależnie więc od tego, czy treść brytyj- 
sadnieniu nowej ustawy z 2014 r., do którego sądy nie sięgnęły, podkreślono, iż:

„Bezsprzecznie moc dowodowa zagranicznych aktów stanu cywilnego nie zależy od ich zarejestrowania w polskim systemie rejestracji stanu cywilnego, a posiadanie takiego dokumentu jest wystarczającym potwierdzeniem urodzenia" ${ }^{31}$.

Nie przekonuje w szczególności teza, że akurat przy transkrypcji na potrzeby postępowań o wydanie dowodu tożsamości (w których toku trzeba obowiązkowo przedstawić transkrybowany zagraniczny akt stanu cywilnego) nie ma możliwości jej odmowy z powołaniem się na klauzulę porządku publicznego (ordre public). Z prawa polskiego wynika treść wręcz odwrotna, ponieważ klauzula została wyrażona w nim nawet wiele razy ${ }^{32}$. Warto podkreślić, że w nowej ustawie p.a.s.c., w porównaniu do starej, celowo dodano kilka przepisów, które klauzulę wyrażają. Na przykład:

Art. 103 p.a.s.c.: „Kierownik urzędu stanu cywilnego albo konsul odmawia rejestracji zdarzenia, jeżeli (...) rejestracja zdarzenia byłaby sprzeczna z podstawowymi zasadami porządku prawnego Rzeczypospolitej Polskiej".

Art. 107 p.a.s.c.: „Kierownik urzędu stanu cywilnego odmawia dokonania transkrypcji, jeżeli: 1) dokument w państwie wystawienia nie jest uznawany za dokument stanu cywilnego (...) lub potwierdza zdarzenie inne niż urodzenie, małżeństwo (...) 3) transkrypcja

skiego aktu urodzenia A.Z. zostałaby «umiejscowiona» w polskich księgach stanu cywilnego, czy też nie, zarówno małoletni, jak i jego opiekun prawny ma możliwość skutecznego powoływania się na ten dokument w obrocie prawnym i jego dowodowego wykorzystania. Zagraniczne akty stanu cywilnego, identycznie jak ich polskie odpowiedniki stanowią wyłączny dowód zdarzeń w nich stwierdzonych (art. 3 p.a.s.c., także wyrok WSA w Gliwicach z dnia 6 maja 2010 r., II SA/ Gl 669/09, ONSA i WSA z 2011 r. poz. 114)".

31 Zob. http://www.sejm.gov.pl/sejm7.nsf/druk.xsp?nr=2620, s. 51, 24.01.2020.

32 Art. 7 p.p.m. „Prawa obcego nie stosuje się, jeżeli jego stosowanie miałoby skutki sprzeczne z podstawowymi zasadami porządku prawnego Rzeczypospolitej Polskiej”.

Art. $1146 \$ 1$ k.p.c. „Orzeczenie nie podlega uznaniu, jeżeli: 7) uznanie byłoby sprzeczne z podstawowymi zasadami porządku prawnego Rzeczypospolitej Polskiej (klauzula porządku publicznego)". byłaby sprzeczna z podstawowymi zasadami porządku prawnego Rzeczypospolitej Polskiej" ${ }^{33}$.

Takie rozwiązanie uzasadniano dążeniem do zagwarantowania efektywniejszej ochrony podstawowych zasad polskiego porządku prawnego oraz formalnego ułatwienia stosowania klauzuli (tj. możliwość wskazania przepisów bezpośrednio w p.a.s.c., a nie pośrednio w p.p.m. i k.p.c.). W uzasadnieniu ustawy podkreślono:

„Kierownik odmówi również dokonania czynności, która byłaby sprzeczna z podstawowymi zasadami porządku prawnego Rzeczypospolitej Polskiej. Dodatkowo w przypadku transkrypcji zarejestrowanie zagranicznego dokumentu stanu cywilnego nie będzie możliwe, jeżeli (...) potwierdza zdarzenie inne niż urodzenie, małżeństwo" ${ }^{34}$.

Natomiast za podejściem przyjętym w uchwale NSA z 2 grudnia 2019 r. przemawiają też inne (niż założenie efektywniejszej ochrony podstawowych zasad polskiego porządku prawnego) motywy ustawodawcy zawarte w uzasadnieniu nowej ustawy z 2014 r. W uzasadnieniu projektu p.a.s.c. podkreślono bowiem, że: „Bezsprzecznie moc dowodowa zagranicznych aktów stanu cywilnego nie zależy od ich zarejestrowania w polskim systemie rejestracji stanu cywilnego, a posiadanie takiego dokumentu jest wystarczającym potwierdzeniem urodzenia (...). Jednak zagraniczne akty stanu cywilnego często nie zawierają wszystkich danych osoby, które wymagane są przepisami polskiego prawa (...) lub też przewidują odmienną od wcześniejszego polskiego aktu stanu cywilnego pisownię nazw własnych (...), lub nie zawierają polskich znaków diakrytycznych. Braki te muszą być uzupełniane, a dane prostowane, $w$ przeciwnym razie nie jest możliwe w świetle polskiego prawa nadanie numeru PESEL lub wydanie dowodu osobistego. (...) Najprostszą drogą uzupełnienia braków w zagranicznych aktach stanu cywilnego jest - w zależności od ich rodzaju - złożenie wniosku lub oświadczenia przed

33 Podobne rozwiązanie zawierają jeszcze: art. 108 ust. 2 i art. 112 p.a.s.c.

34 Zob. Rządowy projekt ustawy - Prawo o aktach stanu cywilnego, Sejm VII kadencji, druk nr 2620, s. 48, http://www. sejm.gov.pl/sejm7.nsf/druk.xsp?nr=2620, 24.01.2020; dalej: uzasadnienie p.a.s.c. 
kierownikiem urzędu stanu cywilnego w związku $\mathrm{z}$ dokonaniem transkrypcji zagranicznego aktu"35.

Wprowadzenie obligatoryjnej transkrypcji w niektórych sytuacjach (wyliczonych w art. 104 ust. 5 p.a.s.c.) nie było więc nastawione na możliwość odejścia od podstawowych zasad polskiego porządku prawnego (które notabene miałyby być w nowej ustawie efektywniej chronione, o czym wyżej). Ustawodawcy przyświecał "techniczny” cel alokowania postępowania dowodowego i ułatwienia uzupełnienia braków infor- stany faktyczne, w których nie następuje przedłożenie w Polsce zagranicznego dokumentu, którego dane są niezbędne do wszczęcia postępowania o transkrypcję. Jednocześnie w tym fragmencie uzasadnienia ustawy celnie podkreślono, że:

„Bezsprzecznie moc dowodowa zagranicznych aktów stanu cywilnego nie zależy od ich zarejestrowania w polskim systemie rejestracji stanu cywilnego, a posiadanie takiego dokumentu jest wystarczającym potwierdzeniem urodzenia".

\section{Zastrzeżenia budzą pojawiające się w pismach} stron postępowań, jak też w stanowisku Rzecznika Praw Obywatelskich, twierdzenia mówiące, że za sporządzeniem polskich aktów urodzenia o treści mówiącej o pochodzeniu dziecka od dwóch osób homoseksualnych miałoby przemawiać „oczywiste orzecznictwo" Europejskiego Trybunału Praw Człowieka oraz Trybunału Sprawiedliwości UE.

macji oraz prostowania danych osobowych nie na etapie wydawania dowodu tożsamości (w postępowaniu w tej sprawie), lecz w toku, „wymuszonego” niejako, postępowania o transkrypcję.

$\mathrm{Na}$ omawiane zagadnienie nie ma wpływu kolejne zdanie mówiące, że: „Rejestrowanie przez kierownika określonych danych w rejestrze PESEL nie może nastąpić w oparciu o zagraniczne akty stanu cywilnego. Rejestr zawierałby bowiem informacje z powyższego zakresu wyłącznie w odniesieniu do osób, które przedłożyłyby taki akt kierownikowi urzędu stanu cywilnego". Na marginesie można zauważyć, że poza niniejszymi rozważaniami (a nawet poza zastosowaniem w praktyce polskiego prawa administracyjnego) są

35 Zob. http://www.sejm.gov.pl/sejm7.nsf/druk.xsp?nr=2620, s. s. $51,24.01 .2020$.
To spostrzeżenie przemawia za, proponowanym niżej, przyjęciem wykładni art. 1138 k.p.c. wynikającej z uchwały SN z dnia 20 listopada 2012 r. też w sprawach o wydanie dowodu tożsamości dziecku, w które zgodnie z obcym dokumentem pochodzi od „rodziców jednopłciowych”, o czym niżej.

\subsection{Nadużywane argumenty o „obowiązach wynikających z prawa unijnego \\ i międzynarodowego"}

Zastrzeżenia budzą pojawiające się w pismach stron postępowań, jak też w stanowisku Rzecznika Praw Obywatelskich, twierdzenia mówiące, że za sporządzeniem polskich aktów urodzenia o treści mówiącej o pochodzeniu dziecka od dwóch osób homoseksualnych miałoby przemawiać „oczywiste orzecznictwo" Europejskiego Trybunału Praw Człowieka oraz 


\title{
Kilka lat temu Komisja UE ogólnie prezentowała
} pomysł uznawania między państwami członkowskimi wpisów do rejestrów stanu cywilnego, ale idea ta

\author{
została zarzucona. Państwa członkowskie (w tym \\ Niemcy i Holandia) podkreśliły, że te zagadnienia \\ mieszczą się poza kompetencjami Unii.
}

Trybunału Sprawiedliwości UE. W szczególności w uzasadnieniu wyroku NSA z 20 października 2018 r. bezpodstawnie wskazano, że rozpoznawana sprawa została „wyjaśniona we wcześniejszym orzecznictwie Trybunału Sprawiedliwości lub prawidłowa wykładnia przepisu prawa europejskiego jest tak oczywista, że nie budzi żadnych racjonalnych wątpliwości”.

Po pierwsze orzecznictwa TSUE na temat krajowych systemów rejestracji stanu cywilnego oraz prawa rodzinnego nie ma i być nie może, ponieważ Unia Europejska nie dysponuje kompetencjami w omawianym zakresie ${ }^{36}$, a co za tym idzie - brak prawa unijnego. Artykuł 5 Traktatu o UE ${ }^{37}$ wyraża zasadę kompetencji przyznanych (powierzonych) słowami „Unia działa wyłącznie w granicach kompetencji przyznanych jej przez państwa członkowskie do osiągnięcia celów określonych w traktatach, a wszelkie kompetencje nieprzyznane Unii w traktatach należą do państw członkowskich" ${ }^{38}$.

36 Zob. R. Kownacki, Ingerencja Karty Praw Podstawowych $w$ zakres realizacji przez państwa członkowskie tematów sensytywnych (eutanazja, związi homoseksualne, aborcja) - propagandowy straszak czy realna perspektywa? (w:) A. Wróbel (red.), Karta Praw Podstawowych w europejskim i krajowym porządku prawnym, Warszawa 2009, s. 387, 390.

37 Dz.U. $2004 \mathrm{nr} 90$ poz. 864/30 ze zm.; wersja skonsolidowana w Dz.U. UE C $2010 \mathrm{nr} 83$.

38 Wojewódzki Sąd Apelacyjny w Krakowie w uzasadnieniu wyroku z dnia 10 maja 2016 r., kontrolowanego przez NSA omawianym wyrokiem, trafnie podkreślił: „Za niemający uzasadnienia w realiach niniejszej sprawy uznać należy zarzut naruszenia art. 7 i 21 ust. 1 Karty Praw Podstawowych Unii
Kilka lat temu Komisja UE ogólnie prezentowała pomysł uznawania między państwami członkowskimi wpisów do rejestrów stanu cywilnego, ale idea ta została zarzucona. Państwa członkowskie (w tym Niemcy i Holandia) podkreśliły, że te zagadnienia

Europejskiej (2007/C 303/01), Traktatu z Lizbony zmieniającego Traktat o Unii Europejskiej i Traktat ustanawiający Wspólnotę Europejską, sporządzonego w Lizbonie dnia 13 grudnia 2007 r. (Dz.U.2009.203.1569), ratyfikowanego przez Rzeczpospolitą Polską ustawą z dnia 1 kwietnia 2008 r. o ratyfikacji Traktatu z Lizbony zmieniającego Traktat o Unii Europejskiej i Traktat ustanawiający Wspólnotę Europejską, sporządzonego w Lizbonie dnia 13 grudnia 2007 r. (Dz.U. nr 62, poz. 388). Zgodnie z art. 7 Karty każdy ma prawo do poszanowania życia prywatnego i rodzinnego, domu i komunikowania się. Zgodnie zaś z art. 21 tejże Karty zakazana jest wszelka dyskryminacja w szczególności ze względu na płeć, rasę, kolor skóry, pochodzenie etniczne lub społeczne, cechy genetyczne, język, religię lub przekonania, poglądy polityczne lub wszelkie inne poglądy, przynależność do mniejszości narodowej, majątek, urodzenie, niepełnosprawność, wiek lub orientację seksualną (ustęp 1 art. 21), a ponadto w zakresie zastosowania Traktatów i bez uszczerbku dla ich postanowień szczególnych zakazana jest wszelka dyskryminacja ze względu na przynależność państwową (ustęp 2 art. 21). Zarzut skarżącej jest bezpodstawny również i z tego powodu, że art. 21 ust. 1 - jak to wynika z wyjaśnień dotyczących Karty Praw Podstawowych (2007/C 303/02) - dotyczy jedynie dyskryminacji ze strony instytucji i organów Unii w wykonywaniu kompetencji przyznanych im na mocy Traktatów oraz ze strony Państw Członkowskich, wówczas gdy wykonują prawo Unii”. 
mieszczą się poza kompetencjami Unii ${ }^{39}$. Od dnia 16 lutego 2019 r. jest stosowane rozporządzenie UE $\mathrm{nr}$ 1191/2016 w sprawie promowania swobodnego przepływu obywateli poprzez uproszczenie wymogów dotyczących przedkładania określonych dokumentów urzędowych w Unii Europejskiej ${ }^{40}$. Rozporządzenie reguluje zwolnienie z legalizacji lub podobnej czynności i uproszczenie innych formalności w odniesieniu do posługiwania się określonymi dokumentami urzędowymi wydanymi przez organy innego państwa członkowskiego. Ustanawia też wielojęzyczne standardowe formularze, które mają być stosowane jedynie jako tłumaczenie pomocnicze załączane do dokumentów urzędowych. Co istotne, w świetle art. 2 ust. 4 „rozporządzenie nie ma zastosowania do uznawania w państwie członkowskim skutków prawnych związanych z treścią dokumentów urzędowych wydawanych przez organy innego państwa członkowskiego". Ten wyraźny przepis podkreślający właśnie, że zagraniczne akty nie wywołują w innych państwach rezultatu materialnoprawnego, został dodany w następstwie sprzeciwu państw wobec pierwotnych planów legislacyjnych Komisji UE, co zostało uzasadnione m.in. brakiem kompetencji $\mathrm{UE}^{41}$. Ostatecznie w rozporządzeniu UE 2016/1191 przewidziano tylko „formalną” problematykę posługiwania się dokumentami wydanymi na bazie zagranicznego rejestru, a pominięto regułę wzajemnego uznawania. Zgodnie $\mathrm{z}$ art. 2 ust. 4 nie ma ono zastosowania do uznawania w państwie członkowskim skutków prawnych związanych z treścią

39 Zob. więcej: P. Mostowik, Legislative Activities of European Union versus Fundamental Principles of Paternity and Maternity in Member States, „International Journal of the Jurisprudence of the Family" 2017, t. 8, s. 79-94, https://papers. ssrn.com/sol3/papers.cfm?abstract_id=3224049, 24.01.2020.

40 Rozporządzenie Parlamentu Europejskiego i Rady (UE) 2016/1191 z dnia 6 lipca 2016 r. w sprawie promowania swobodnego przepływu obywateli poprzez uproszczenie wymogów dotyczących przedkładania określonych dokumentów urzędowych w Unii Europejskiej i zmieniające Rozporządzenie (UE) nr 1024/2012, Dz.U. UE L nr 200, s. 1.

41 Zob. więcej: P. Mostowik, Kwestia zakresu zastosowania rozporzadzenia UE nr 1191/2016 do zagranicznej rejestracji stanu cywilnego, „Rodzina i Prawo” 2016, nr 37, s. 97 i n., https://ruj.uj.edu.pl/xmlui/handle/item/37262, 24.01.2020. dokumentów urzędowych wydawanych przez organy innego państwa.

Wyłączne znaczenie prawa krajowego podkreśla się w ostatnim orzecznictwie TSUE, $\mathrm{w}$ tym $\mathrm{w}$ wyroku TSUE z 5 czerwca 2018 r. $^{42}$ (sprawa Coman), o dziwo przytaczanym w pismach Rzecznika Praw Obywatelskich i uzasadnieniu krytykowanych wyroków na rzecz odwrotnego stanowiska. W punkcie 37 uzasadnienia tego wyroku TS UE wskazano: „Oczywiście kwestie stanu cywilnego (...) są materią należącą do kompetencji państw członkowskich i prawo Unii tej kompetencji nie narusza”, natomiast w punkcie 43: „Unia szanuje tożsamość narodową państw członkowskich, nierozerwalnie związaną z ich podstawowymi strukturami politycznymi i konstytucyjnymi" ${ }^{43}$.

Po drugie z omawianą problematyką ściśle wiąże się zagadnienie nabywania stanu cywilnego drogą kontraktu z tzw. surrogate mother, co dotyczy w szczególności „rodziców jednopłciowych” (w praktyce osób homoseksualnych) płci męskiej, którzy w Polsce legitymować się będą zagranicznym aktem urodzenia z ich danymi (np. w stanie faktycznym leżącym u podstaw wyroków NSA z 6 maja 2015 r. $)^{44}$. Dla homoseksualnych par mężczyzn jest to w niektórych państwach prawny sposób uzyskania statusu pierwotnych rodziców tego samego dziecka.

W europejskich instytucjach politycznych pojawiają się ostatnio wyrazy niechęci odnośnie do praktyk surrogate motherhood, których rezultatem są zagraniczne

42 Wyrok z dnia 5 czerwca 2018 r. w sprawie C-673/16 (sprawa Coman v. Rumunia), http://curia.europa.eu/juris/document/ document.jsf .docid $=202542 \&$ mode $=$ req \&pageIndex $=1 \&$ di $\mathrm{r}=\&$ occ $=$ first $\&$ part $=1 \&$ text $=\&$ doclang $=$ PL\&cid $=301542 \#$ Fo otnote, 24.01.2020.

43 Zob. podobnie wyroki: z dnia 2 października 2003 r., Garcia Avello, C-148/02, EU:C: 2003: 539, pkt 25; z dnia 1 kwietnia 2008 r., Maruko, C-267/06, EU:C: 2008: 179, pkt 59; z dnia 14 października 2008 r., Grunkini Paul, C-353/06, EU:C: 2008: 559, pkt 16; państwa członkowskie mają zatem swobodę (a nie obowiązek - przyp. P.M.) w zakresie wprowadzenia małżeństwa dla osób tej samej płci (Wyrok z dnia 24 listopada 2016 r., Parris, C-443/15, EU:C: 2016:897, pkt 59).

44 Wyrok NSA z 6 maja 2015 r., II OSK 2372/13, http://orzeczenia.nsa.gov.pl/doc/12EBFE1F1E; Wyrok NSA z 6 maja 2015 r., II OSK 2419/13, http://orzeczenia.nsa.gov.pl/doc/ A7BCB1D1A8, 24.01.2020. 
dokumenty o treści, która może nie podlegać uznaniu w innych państwach (np. w Polsce). Na przykład Parlament Unii Europejskiej w raporcie na temat praw człowieka i demokracji w świecie z 2014 r. i polityki Unii Europejskiej w tej dziedzinie zdecydowanie kry- umowę międzynarodową celem uznawania zagranicznego statusu prawnego rodziców (filiacji) nabytego za granicą na podstawie kontraktu z surrogate mother. Tę krytykę oparto na tezie, że możliwość takiego kontraktowania narusza godność kobiety ${ }^{46}$.

\section{W europejskich instytucjach politycznych pojawiają} się ostatnio wyrazy niechęci odnośnie do praktyk surrogate motherhood, których rezultatem są zagraniczne dokumenty o treści, która może nie podlegać uznaniu w innych państwach (np. w Polsce).

tycznie odniósł się do praktyk tzw. macierzyństwa zastępczego. W ust. 114 raportu potępiono „praktykę macierzyństwa zastępczego, które podważa ludzką godność kobiety, ponieważ jej ciało i jej funkcje rozrodcze są używane jako towar" ${ }^{35}$.

W ostatnim czasie europejskie feministyczne organizacje społeczne wyraziły daleko idącą krytykę w stosunku do pomysłu w ramach Haskiej Konferencji Prawa Prywatnego Międzynarodowego, by opracować

45 Zob. Report of 30 November 2015 on the Annual Report on Human Rights and Democracy in the World 2014 and the European Union's policy on the matter, 2015/2229(INI), http:// www.europarl.europa.eu/doceo/document/A-8-2015-0344_ EN.html?redirect, 24.01.2020. Zob. też dokumenty autorstwa Rady Europy zawarte w aneksie publikacji P. Mostowik (red.), Fundamentalne prawne problemy surrogate motherhood. Perspektywa krajowa, Warszawa 2019, s. 787 i n. Ewolucję zjawiska zwanego surrogate motherhood w kierunku sposobu dostarczania dzieci, w tym z dookreśleniem cech fizycznych (np. koloru oczu i włosów) i prawdopodobnych osobowych (za pośrednictwem wykształcenia genetycznych rodziców), mogą obrazować oferta ukraińskiego ośrodka: http://biotexcom.com/information/brief-explanation-surrogacy-process (24.01.2020) oraz zbiórka społeczna na pomoc parze homoseksualnych młodzieńców w sfinansowaniu nabycia dziecka w Republice Południowej Afryki: www.babyrainbow. $\mathrm{nl}(24.01 .2020)$.
Po trzecie warto przybliżyć rzeczywistą treść wiążącego Polskę prawa międzynarodowego, w tym Konwencji ONZ o prawach dziecka z 1989 r. ${ }^{47}$ Celnie WSA w Poznaniu w uzasadnieniu wyroku z 5 kwietnia 2018 r. zauważa szczególnie, że „[c] o również istotne, Polska miała znaczący udział w tworzeniu Konwencji - składając propozycje do tekstu Konwencji i będąc w pierwszej grupie państw, które ją podpisały (...)”. Za tą obserwacją idzie jednak interpretacja przez WSA treści normatywnej, której z pewnością państwa tworzące konwencję nie akceptowały ani nie przewidywały. Nie idzie natomiast zastosowanie międzynarodowego prawa prywatnego i postępowania cywilnego, które

46 Zob. Contribution of Feminist and Human Rights Organizations to the Work of The Hague Conference on Private International Law Regarding Legal Issues Concerning International Surrogacy Conventions ("Parentage/Surrogacyproject”). Comments on Preliminary Document No 3 B of March 2014 and Preliminary Document No 3A of February 2015, https://collectifcorp.files.wordpress.com/2015/01/surrogacy_hcch_feminists_english.pdf, 24.01.2020.

47 Konwencja o prawach dziecka przyjęta przez Zgromadzenie Ogólne Narodów Zjednoczonych dnia 20 listopada 1989 r., Dz.U. 1991 nr 120, poz. 526 ze zm.; dalej: Konwencja o prawach dziecka z 1989 r. Na temat genezy zob. T. Smyczyński (red.), Konwencja o prawach dziecka. Analiza i wykładnia, Poznań 1999, s. 10 i n. 
jest kluczowe dla rozpoznawanych przez organy i sądy administracyjne $-\mathrm{w}$ istocie cywilnych spraw.

W świetle art. 7 Konwencji o prawach dziecka z 1989 r.: „1. Niezwłocznie po urodzeniu dziecka zostanie sporządzony jego akt urodzenia, a dziecko od momentu urodzenia będzie miało prawo do otrzymania imienia, uzyskania obywatelstwa oraz, jeśli to możliwe, prawo do poznania swoich rodziców i pozostawania pod ich opieką. 2. Państwa-Strony zapewnią, aby te prawa stały się zgodne $\mathrm{z}$ ich prawem wewnętrznym oraz z ich międzynarodowymi zobowiązaniami w tej dziedzinie, w szczególności w przypadkach, gdyby brak tych uregulowań spowodował, iż dziecko zostałoby bezpaństwowcem”. Przepis ten mówi wyraźnie o prawie do poznania swoich rodziców, przez których umawiające się państwa z pewnością nie rozumiały drugiej osoby tej samej płci (tj. nie wyrażały konsensu na takie rozumienie konwencji, decydując o przystąpieniu do niej).

Zgodnie zaś art. 8 Konwencji o prawach dziecka Państwa-Strony winny okazać właściwą pomoc i ochronę w celu jak najszybszego przywrócenia jego tożsamości w wypadku, gdy dziecko zostało bezprawnie pozbawione części lub wszystkich elementów swojej tożsamości. Za takie pozbawienie tożsamości uznać by można generalne zignorowanie w akcie urodzenia faktu stosunków rodzinnych, tj. faktu, od kogo dane dziecko pochodzi (a nawet szerzej - może pochodzić). Ponadto w postanowieniach umów międzynarodowych wyrażane są zakazy handlu dziećmi oraz negatywne nastawienie do nabywania stanu cywilnego rodziców drogą odpłatnej czynności prawnej, w efekcie których powstają właśnie zagraniczne dokumenty stanu cywilnego z dwoma „rodzicami” tej samej płci ${ }^{48}$.

Natomiast Europejski Trybunał Praw Człowieka, którego orzeczenia - nie zawsze na temat, a niekiedy bez związku ze sprawą - zostały w pismach powołane $\mathrm{w}$ toku postępowania (co jest współczesną manierą w działalności niektórych podmiotów), nie zajmował się dotychczas identyczną sprawą.

48 Np. wymaganie nieodpłatności adopcji na tle Konwencji o ochronie dzieci i współpracy w dziedzinie przysposobienia międzynarodowego, sporządzonej w Hadze dnia 29 maja 1993 r., Dz.U. 2000 nr 39 poz. 448 ze sprost.
Wielka Izba Europejskiego Trybunału Praw Człowieka w wyroku w sprawie Paradiso i Campanelli v. Włoch ${ }^{49}$, który to wyrok powinien zostać dokładniej zbadany przez sąd, sprecyzowała wcześniejsze wypowiedzi na temat pieczy nad dzieckiem (a nie prawnego określenia stosunków filiacyjnych). Zmodyfikowano wcześniejsze orzeczenie w tej sprawie wydane w mniejszym składzie. Ostatecznie stwierdzono brak naruszenia art. 8 EKPC w stosunku do dziecka, które nie było związane genetycznie z jego "nabywcą" od surrogate mother. Podkreślono, że art. 8 EKPC nie gwarantuje prawa do założenia rodziny ani prawa do „otrzymania” adoptowanego dziecka. W uzasadnieniu, odchodząc od tez orzeczenia zapadłego w węższym składzie, podkreślono, że nad subiektywną indywidualną wolą posiadania dziecka przeważają pewne ogólnie uzasadnione dobra. W szczególności za konieczne uznano wzięcie pod uwagę więzi biologicznej z uwagi na krótki okres wzajemnej osobistej styczności. W wypadku dwóch osób tej samej płci więź biologiczna z dzieckiem odnosi się z istoty tylko do jednej z nich, co na tle szeregu systemów prawnych, w tym polskiego, rzutuje na podstawowe kategorie materialnoprawne. Sąd Administracyjny celnie w uzasadnieniu wyroku z dnia 28 lutego 2018 r. podkreślił, że „organy administracji publicznej obowiązane są przestrzegać Konstytucji RP i obowiązujących ustaw. Do takich ustaw należy m.in. kodeks rodzinny i opiekuńczy"50.

Natomiast w najnowszej opinii ETPC z 10 kwietnia 2019 r. $^{51}$, która została wydana po omawianym orzecz-

49 Wyrok ETPC z 24 stycznia 2017 r., skarga nr 25358/12. Zob. więcej Ł. Mirocha, Tzw. macierzyństwo zastępcze (surrogacy, Leihmutterschaft) $w$ bieżacym orzecznictwie Europejskiego Trybunału Praw Człowieka w Strasburgu, „Prawo w Działaniu” 2018, t. 34, s. 164, https://iws.gov.pl/wp-content/ uploads/2018/08/IWS-Mirocha-Ł.-Tzw.-macierzyństwo-zastępcze-surrogacy-Leihmutterschaft-w-bieżącym-orzecznictwie-Europejskiego-Trybunału-Praw-Człowieka-w-Strasburgu.pdf, 24.01.2020.

50 Wyrok Naczelnego Sądu Administracyjnego z dnia 28 lutego 2018 r., II OSK 1112/16, LEX nr 2495844.

51 Opinia doradcza z 10 kwietnia 2019 r. dotycząca uznania w prawie krajowym stosunku prawnego rodzic-dziecko między dzieckiem urodzonym w ramach surogacji za granicą a matką intencyjną. Wniosek francuskiego sądu kasacyjnego (wniosek nr P16-2018-001). 
nictwie NSA i WSA, stwierdzono wręcz odwrotnie niż w uzasadnieniach polskich wyroków (pkt 2 zd. 1). Trybunał wyraźnie stwierdził m.in., że „prawo dziecka do poszanowania życia prywatnego w rozumieniu art. 8 EKPC nie wymaga, aby takie uznanie [jakiejś relacji między dzieckiem a małżeństwem, które dziecko pozyskało - przyp. P.M.] przybrało formę wpisu do rejestru urodzeń, małżeństw i zgonów szczegółowej treści aktu urodzenia sporządzonego za granicą zgodnie z prawem obcym”. Tym bardziej taki brak obowiązku akceptacji zagranicznej treści rejestru stanu cywilnego dotyczy sytuacji dalej idących różnic między systemami prawnymi, tj. dodatkowo (prócz kwestii handlowej surogacji) odmienności polegającej na tym, że obce prawo przewiduje diametralne inne ujęcie prawnego pochodzenia dziecka (homoseksualne).

ETPC w żadnym z wyroków nie wskazywał, że należy zmieniać krajowy system rejestracji stanu cywilnego celem „importowania” doń jakiejkolwiek tak nazywanej zagranicznej działalności. Nawet gdyby Trybunał zajmował się sprawami podobnymi do spraw rozpoznanych przez NSA wyrokami z 20 czerwca 2018 r. i 10 października 2018 r., to prawdopodobnie skoncentrowałby się na tym, czy dziecko rzeczywiście pochodzi od obywatela skarżonego państwa, oraz na tym, że nie należy zbytnio (nie znaczy wcale) utrudniać korzystania z prawnych konsekwencji tego faktu. Do tego ostatniego wystarczałoby przełamanie obowiązku posłużenia się dowodem $\mathrm{z}$ aktu transkrybowanego w Polsce na rzecz dopuszczenia możliwości posłużenia się innym dowodem (np. bezpośrednio dokumentem zagranicznym częściowo uznawanym zgodnie $z$ art. 1138 k.p.c.).

Trzeba też wskazać, że nawet na tle - mniej powiązanych z pierwotnym pochodzeniem dziecka (stanem cywilnym) - spraw adopcji dzieci oraz kwestii poszerzenia tej konstrukcji prawnej na osoby tej samej płci w rejestrowanych związkach partnerskich, ETPC w wyroku z 15 marca 2012 r. ${ }^{52}$ stwierdził, że kwestia naruszenia art. 14 Konwencji i zarzut dyskryminacji może być ewentualnie rozpatrywany, jeżeli zachodzi różnica w traktowaniu osób znajdujących się w porównywalnych położeniach. Różnica taka jest dyskrymi-

52 Wyrok ETPC z 15 marca 2012 r., skarga 25951/07; LEX nr 1130706. nująca, gdy nie posiada obiektywnego i rozsądnego uzasadnienia. Trybunał podkreślił, że państwom konwencyjnym przysługuje margines uznania przy rozstrzyganiu, czy i w jakim zakresie różnice w położeniach, pod niektórymi tylko względami podobnych, uzasadniają różne traktowanie, włącznie z różnicami w traktowaniu w świetle prawa. Trybunał w tej sprawie nie stwierdził naruszenia art. $14 \mathrm{w}$ związku $\mathrm{z}$ art. 8 Konwencji.

Warto zwrócić też uwagę na wyrok niemieckiego sądu najwyższej instancji z 2019 r., w którym - odmiennie od części tez, które pojawiły się w polskiej judykaturze - przesądzono, że nie podlega przerejestrowaniu w kraju zagraniczny akt urodzenia (ukraiński), którego treść jest sprzeczna z prawem państwa rejestru ${ }^{53}$. Stan rzeczy w tej sprawie był podobny do stanów sprawy sygnalizowanych powyżej z uwagi na właściwość prawa rodzinnego państwa sądu oraz sprzeczność obcego prawa i aktu stanu cywilnego z podstawowymi zasadami porządku prawnego forum.

\section{Kwestia rozumienia zasady dobra dziecka in concreto oraz in genere}

Omawiane orzecznictwo stwarza też pole do wypowiedzi na temat rozumienia zasady dobra dziecka. Odwołanie się do generalnej zasady dobra dziecka w omawianych kazuistycznych sprawach ma bardzo specyficzną treść. Otóż z uzasadnień tych wyroków zdaje się płynąć myśl, że prawne rozumienie pochodzenia dziecka (macierzyństwo i ojcostwo) nie powinno być rozumiane za biologicznymi okolicznościami urodzenia dziecka, które leżą u podstaw prawa krajowego, ale że te ostatnie miałyby in casu ustępować innym regułom, w tym generalnym fikcjom prawnym w obcych systemach prawnych.

Nie przekonuje przy tym na przykład ogólne założenie możliwości wywodzenia z zasady dobra dziecka rozwiązania, które miałoby polegać na tym, że kazuistyczne okoliczności sprawy (w tym aktualna osobista styczność dziecka z określonymi osobami) powinny być okolicznościami decydującymi o tym,

53 Zob. więcej E. Figura-Góralczyk, Uwagi dotyczące orzeczenia Niemieckiego Sądu Związkowego z 20 marca 2019 (BGH XII ZB 530/17) (w:) P. Mostowik (red.), Fundamentalne prawne problemy surrogate motherhood..., dz. cyt., s. 521 i n. 
od kogo to dziecko generalnie pochodzi. W dotychczasowym rozwoju prawa ocena pochodzenia dziecka (w tym na potrzeby sporządzenia aktu urodzenia z danymi rodziców) była dokonywana na podstawie faktów z momentu urodzenia, a nie późniejszych okoliczności (np. po kilku latach w chwili rozpatrywania sprawy o wydanie dowodu tożsamości). Co ważniejsze, w polskim stanie prawnym, składającym się z norm o genezie krajowej i międzynarodowej, dobro dziecka rozpatrywane jest $\mathrm{w}$ znaczeniu generalnym oraz przy uwzględnieniu całego systemu prawnego.

Wykładni art. 72 Konstytucji RP z 1997 r., w którym jest mowa o „ochronie praw dziecka”, oraz przepisów umów międzynarodowych i ustaw krajowych trzeba dokonywać w zgodzie z podstawowymi zasadami ustrojowymi i kodeksowymi ${ }^{54}$. Dobro dziecka ustawodawca polski na gruncie przepisów o jego pochodzeniu, o których mowa, rozumie i gwarantuje w ten sposób, że oddają one naturalne (biologiczne) macierzyństwo i ojcostwo, do czego jest dopasowany sposób prowadzenia krajowego systemu rejestracji stanu cywilnego (w tym transkrypcji) ${ }^{55}$. Początek XXI w.

54 Zob. więcej W. Borysiak (w:) M. Safjan, L. Bosek (red.), Konstytucja RP. Art. 1-86. Komentarz, Warszawa 2016, s. 478 i n.

55 Inaczej odnośnie do rozumienia zasady dobra dziecka - choć nie na tle postępowania o transkrypcję, lecz postępowania w sprawie szczegółowej (stwierdzenia obywatelstwa dziecka)M. Pilich, Mater semper certa est? Kilka uwag o skutkach zagranicznego macierzyństwa zastępczego z perspektywy stosowania klauzuli porzadku publicznego, „Problemy Współczesnego Prawa Międzynarodowego, Europejskiego i Porównawczego" 2018, t. 16, s. 7-35 oraz A. Wysocka-Bar, Nabycie polskiego obywatelstwa a urodzenie przez matkę zastępczą. Uwagi na tle wyroków Naczelnego Sądu Administracyjnego $z$ dnia 6 maja 2015 r.: II OSK 2372/13 oraz II OSK 2419/13, „Problemy Współczesnego Prawa Międzynarodowego, Europejskiego i Porównawczego” 2018, t. 16, s. 38-54. Stanowiska tych autorów nie przekonują właśnie z zasadniczych powodów opisanych wyżej w ramach zastrzeżeń do krytykowanych orzeczeń z 2018 r. oraz z uwagi na brak wzięcia przez autorów pod uwagę kompleksowych skutków proponowanego przez nich „przymknięcia oka” na podstawowe zasady polskiego prawa osobowego i rodzinnego celem załatwienia kazuistycznej sprawy wydania dowodu tożsamości dziecka, którą można załatwić w - postulowany niżej - inny, proporcjonalny sposób. Ponadto wskazani autorzy de facto pomijają w swej argu- przyniósł niespotykane w dotychczasowym rozwoju prawa różnice między założeniami prawa rodzinnego i systemów rejestracji stanu cywilnego w poszczególnych państwach. Nie znajduje uzasadnienia podejście, które jest widoczne w krytykowanych wyrokach, polegające na dostosowaniu polskiego systemu rejestracji stanu cywilnego do obcych reguł prawa materialnego, których treść nie jest zgodna z podstawowymi zasadami polskiego porządku prawnego ${ }^{56}$.

Trzeba mieć też na względzie, że w świetle art. 16 Konwencji o prawach dziecka z 1989 r. dziecko nie może podlegać arbitralnej lub bezprawnej ingerencji w sferę jego życia prywatnego lub rodzinnego, dziecko ma prawo do ochrony prawnej przeciwko tego rodzaju ingerencji lub zamachom. $Z$ perspektywy podstawowych zasad prawa polskiego - kluczowego $\mathrm{z}$ uwagi na regułę lex fori processualis - zasadę tę naruszać może nie odmowa rejestracji w Polsce, ale właśnie obce rozwiązanie, którego treść miałaby zostać powielona w polskim rejestrze urodzeń, ponieważ polega ono na tym, że treść zagranicznego dokumentu „odziera” dziecko z biologicznej i genetycznej tożsamości pochodzenia (na rzecz fikcji prawnej filiacji od dwóch osób tej samej płci). Dodać trzeba, że prawne reguły pochodzenia dziecka są w większości systemów prawnych na świecie powiązane z ogólnymi regułami biologii poczęcia dziecka, a nie z orientacją seksualną rodziców. Oczywiście dziecko może pochodzić biologicznie również od osób homoseksualnych, tyle że dwie osoby tej samej płci nie mogą być rodzicami tego samego (wspólnego) dziecka. Perspektywa prawna zagranicznego urzędu stanu cywilnego może być inna, np. w uwagi na fikcje prawne w obcym prawie

mentacji podstawową okoliczność, że na tle prawa polskiego, które jest właściwe w sprawie (art. 55 p.p.m.) - podobnie jak na tle szeregu systemów prawych na świecie - nadal mater semper certa est. Nieważne jest zaś kontraktowanie z tzw. surogatką, które rodziłoby alternatywną i konkurencyjną zasadę prawną odnośnie do prawego pochodzenia dziecka. Zob. więcej C. Martinez de Aguirre, Umowy o międzynarodowe macierzyństwo zastępcze: globalna. Opowieść podręcznej? (w:) P. Mostowik (red.), Fundamentalne prawne problemy surrogate motherhood..., dz. cyt., s. 289 i n.

56 Tak P. Mostowik, Problem obywatelstwa dziecka prawdopodobnie pochodzącego od obywatela polskiego niebędącego mężem surrogate mother..., dz. cyt., s. 67-70. 
stosowanym przez niego z urzędu, ale nie ma to znaczenia dla oceny rozumienia i podstawowych zasad stanu cywilnego w innym państwie, w tym w Polsce ${ }^{57}$.

\section{Wartość spójności krajowego systemu prawa osobowego i rodzinnego oraz rejestracji stanu cywilnego}

Istotnym argumentem za utrzymaniem dotychczasowej linii orzeczniczej wyrażonej np. w wyroku NSA z 20 czerwca 2018 r. oraz w uchwale NSA z 2 grudnia 2019 r. jest obserwacja, że krytykowany wyrok został wydany celem rozwiązania problemów zidentyfikowanych nie na tle ogólnego postępowania o transkrypcję, ale na tle innych postępowań administracyjnych. Ponadto trzeba zaakcentować, że może on w przyszłości nieproporcjonalnie doprowadzić do generalnego zburzenia „od środka” polskiego systemu rejestracji stanu cywilnego, a nawet naruszyć fundamenty prawa ustrojowego i rodzinnego w polskim porządku prawnym ${ }^{58}$.

Na tle omawianych stanów faktycznych trzeba się najpierw zastanowić, czy poprawne jest rozważanie zastosowania klauzuli porządku publicznego przewidzianej w art. 107 pkt 3 p.a.s.c., czy też kwestia, która się wyłania, podlega ogólniejszym zasadom

57 Stąd trudno jako niepoprawną ocenić tezę WSA w Krakowie $\mathrm{z}$ uzasadnienia kontrolowanego przez NSA wyroku z dnia 10 maja 2016 r., mówiącą, że: „W świetle powyższego nie może budzić wątpliwości, że wpisanie do polskich ksiąg stanu cywilnego treści zagranicznego aktu urodzenia, który obok matki dziecka jako drugiego rodzica wymienia kobietę, w konsekwencji czego rodzicami dziecka są osoby tej samej płci, stanowiłoby pogwałcenie podstawowych zasad polskiego porządku prawnego. Zdaniem Sądu, nie zmieniają tego powołane przez skarżącą przepisy szeroko pojętego prawa międzynarodowego, jak i orzecznictwo Europejskiego Trybunału Praw Człowieka, czy też Europejskiego Trybunału Sprawiedliwości. Przepisy te nie nakazują stanowienia w krajowym porządku prawnym regulacji innego kraju dotyczących związków jednopłciowych czy regulacji uwzględniających jako rodziców dziecka dwóch osób tej samej płci”.

58 Zob. M. Wojewoda, Transkrypcja zagranicznego dokumentu stanu cywilnego - kilka uwag na temat ewolucji konstrukcji w prawie polskim, „Metryka” 2016, nr 2, s. 53 i n.; tenże, Transkrypcja aktu urodzenia dziecka, które zostało uznane za granica, dz. cyt., s. 347-350. prawa o aktach stanu cywilnego i prawa rodzinnego. Wydaje się, że za załatwieniem sprawy w sposób przyjmowany dotychczas, w tym w sposób opisany w wyroku NSA z 20 czerwca 2018 r., przemawiają względy ogólniejsze niż podstawowe zasady transkrypcji, tj. bardziej generalne zasady krajowej rejestracji stanu cywilnego wyrażone w art. art. 103 i 104 oraz ust. 2 art. 105 p.a.s.c. W art. 2 ust. 3 p.a.s.c. jest mowa o tym, że „[a]ktem stanu cywilnego jest wpis o urodzeniu, małżeństwie albo zgonie $\mathrm{w}$ rejestrze stanu cywilnego", przy czym z art. 60 pkt 4 wynika, że treścią aktu urodzenia są też dane na temat pochodzenia dziecka, tj. nazwiska, imiona oraz nazwiska rodowe matki i ojca. Tym samym rejestr obejmuje też prawną problematykę macierzyństwa i ojcostwa w rozumieniu działu Ia („Rodzice i dzieci”) rozdziału I („Pochodzenie dziecka”) k.r.o.

Pojęcie „akt stanu cywilnego”, także na potrzeby art. 104 i n. dotyczących transkrypcji, trzeba rozumieć zgodnie z prawem państwa rejestracji (tu: transkrypcji), w tym zgodnie z podstawowymi konstrukcjami prawa polskiego dotyczącymi pochodzenia dziecka i małżeństwa. Z tych zasad, co zostało trafnie wskazane w aprobowanej części orzecznictwa sądów administracyjnych, wynika, że na tle prawa polskiego rodzicami dziecka są - za biologią - kobieta i mężczyzna. Tym samym stan cywilny z jednej strony pochodzenia dziecka, a z drugiej strony - macierzyństwa i ojcostwa, obejmuje relację (filiację) między dzieckiem a kobietą i mężczyzną. Inne konfiguracje osobowe, w tym relacja dziecka $\mathrm{z}$ więcej niż dwoma osobami albo z osobami tej samej płci, nie wypełniają znamion krajowego rozumienia stanu cywilnego. Tym samym zagraniczny dokument w części zaświadczającej taką odmienną relację nie oddaje stanu cywilnego w krajowym rozumieniu (co najmniej w jego części dotyczącej posiadania dziecka z drugą osobą tej samej płci). Decydujący winien być materialnoprawny charakter zaświadczonej relacji, a nie nazwa zagranicznego dokumentu „akt stanu cywilnego" lub podobna. Notabene niektóre zagraniczne dokumenty są inaczej nazywane (np. certyfikat porodu), ale podlegają transkrypcji w Polsce z uwagi na ich treść odpowiadającą atrybutom krajowego rozmienia rodzicielstwa.

$\mathrm{Z}$ tych powodów z art. 103 i 104 p.a.s.c. można wywieść, że kierownik odmawia rejestracji zdarze- 
nia, jeżeli dokument lub jego część (np. pochodzenie od drugiej osoby tej samej płci) nie obejmuje de facto stanu cywilnego, który podlega rozumieniu zgodnie z prawem państwa transkrypcji. Prawo polskie materialne nie zna bowiem konstrukcji „rodziców tej samej płci” ani „pochodzenia dziecka od osób tej samej płci", nazwanych celnie z tej perspektywy przez NSA w uzasadnieniu wyroku z 20 czerwca 2018 r. con- ważnością kontraktowego nabycia stanu cywilnego rodzica drogą umowy z surrogate mother albo drogą adopcji, która naturam non imitatur. Z art. 107 p.a.s.c. można więc wyinterpretować, że kierownik odmawia rejestracji, jeżeli zgodnie z własnym prawem (państwa transkrypcji, czyli polskim) przedstawiony dokument też częściowo - nie jest uznawany za dokument stanu cywilnego, bo jest w nim np. mowa o pochodzeniu

\section{Prawo polskie materialne nie zna konstrukcji} „rodzice tej samej płci” ani „pochodzenie dziecka od osób tej samej płci”, nazwanych celnie z tej perspektywy przez NSA w uzasadnieniu wyroku z 20 czerwca 2018 r. contradictio in se.

tradictio in se. Stąd zagraniczny dokument w części wyrażającej taką treść (podobnie jak obejmujący dwie osoby tej samej płci w akcie małżeństwa) nie musi być traktowany jako dokument dotyczący stanu cywilnego. Stan cywilny, w tym macierzyństwo i ojcostwo oraz małżeństwo, powinien bowiem, dla utrzymania konsekwencji p.a.s.c. oraz k.r.o. i poszanowania reguł konstytucyjnych, być rozumiany spójnie.

Natomiast w świetle art. 107 pkt 3 p.a.s.c. kierownik urzędu stanu cywilnego odmawia dokonania transkrypcji, jeżeli przedłożony dokument potwierdza zdarzenie inne niż urodzenie lub małżeństwo. W omawianych wypadkach część treści zagranicznego dokumentu potwierdza zdarzenie inne niż urodzenie oraz, powiązane z nim, macierzyństwo i ojcostwo. Część zagranicznego dokumentu nie potwierdza urodzenia dziecka od określonej kobiety i mężczyzny, co jest zasadą prawa polskiego, a wręcz odwrotnie - statuuje fikcję prawną pochodzenia dziecka od drugiej osoby tej samej płci. Dodatkowo w niektórych sytuacjach („pochodzenia dziecka od dwóch mężczyzn”) dokument ten wyraża obce rozwiązanie prawne, które nie podlega uznaniu z uwagi na sprzeczność z podstawowymi zasadami polskiego porządku prawnego, tj. $\mathrm{z}$ nie- dziecka od dwóch mężczyzn. Druga osoba tej samej płci wpisana obok pierwszej na pewno w świetle krajowych podstawowych zasad nie jest prawnie uznawana jako małżonek (czyli nie ma wówczas aktu małżeństwa w rozumieniu p.a.s.c.) ani drugi z rodziców (czyli co najmniej częściowo nie ma aktu urodzenia według p.a.s.c.). Wówczas kierownik urzędu stanu cywilnego, z uwagi na dyspozycję art. 107 pkt 1 i 2 p.a.s.c., odmawia dokonania transkrypcji bez potrzeby zastosowania klauzuli, ponieważ zagraniczny dokument potwierdza zdarzenie w samej konstrukcji inne niż urodzenie, małżeństwo w rozumieniu legis fori. Te ostatnie zdarzenia trzeba bowiem rozumieć jako pochodzenie dziecka lub urodzenie według prawa polskiego, bo to prawo obowiązuje urzędników oraz jest właściwe zgodnie z prawem prywatnym międzynarodowym (prawo właściwe zgodnie $\mathrm{z}$ art. 55 p.p.m.).

Nie do obrony jest przy tym teza, którą można wywieść z uzasadnienia wyroku NSA z 10 października 2018 r., mówiąca, że art. 107 p.a.s.c. nie ma zastosowania w niektórych sprawach o transkrypcję z uwagi na to, że w art. 104 ust. 5 p.a.s.c., który rozpoczyna się słowami „[t]ranskrypcja jest obligatoryjna”. Odnoszą się one do wymagania dowodowego (obowiąz- 
kowego przedłożenia dowodu w postaci aktu transkrybowanego do polskiego rejestru), które zostało podwyższone odnośnie do niektórych postępowań szczególnych (de facto przyszłych), a nie ogólnego postępowania o transkrypcję. Tej ostatniej dotyczy zaś bez wątpienia, co podkreślił NSA w uchwale z 2 grudnia 2019 r., art. 107 p.a.s.c., którego celem jest m.in. zablokowanie przeniesienia do polskiego rejestru zagranicznego wpisu, jeżeli „dokument (...) potwierdza zdarzenie inne niż urodzenie (...) lub transkrypcja byłaby sprzeczna z podstawowymi zasadami porządku prawnego Rzeczypospolitej Polskiej”. Jeżeli w zagranicznym dokumencie widnieją dwaj mężczyźni (np. nabywcy statusu rodziców w drodze kontraktu z tzw. surogatką), trudno traktować go jako dokument potwierdzający urodzenie. Zawsze, w razie zamieszczenia w nim osób tej samej płci jako rodziców, co celnie w dotychczasowym orzecznictwie określano jako sprzeczność samą w sobie (contradictio in se), wytworzenie krajowego dokumentu o skutkach opisanych w art. 3 p.a.s.c. byłoby sprzeczne z podstawowymi zasadami porządku prawnego.

\section{Wattpliwości dotyczące postulatu tzw. częściowej transkrypcji oraz rejestracji wzmianki}

Nie przekonują przy tym propozycje „połówkowych" rozstrzygnięć w uzasadnieniu wyroku WSA w Poznaniu z 5 kwietnia 2018 r., w tym sugerowanego sposobu wykładni p.a.s.c., polegającej na dokonywaniu tzw. częściowej transkrypcji zagranicznego aktu stanu cywilnego w drodze zastosowania klauzuli porządku publicznego opisanej w ust. 3 art. 104 p.a.s.c. odnośnie do części treści zagranicznego dokumentu (odrzucenie części treści zagranicznej rejestracji, tj. drugiej kobiety zamiast ojca dziecka, jako sprzecznej z podstawowymi zasadami polskiego porządku prawnego). Wydaje się, że wprowadzenie takiej możliwości wywoływałoby więcej negatywnych konsekwencji niż skutków pozytywnych. Po pierwsze takie rozwiązanie mogłoby u osób mieszkających za granicą (a takiego rodzica w praktyce będzie dotyczyć) rodzić pretensję, że w transkrybowanym akcie został dopisany fikcyjnie mężczyzna (dane kryjące), albo pretensję o pominięcie drugiej z osób zarejestrowanych za granicą. Pod drugie odstąpienie od dopisania danych fikcyjnego ojca i pozostawienie pustego miejsca oznaczałoby wyłom w polskim systemie rejestracji stanu cywilnego, dla którego przekonującym argumentem mogłaby jednak nie być specyfika transkrypcji.

Niepożądane wydaje się więc przyjęcie jako rozwiązania częściowej (połówkowej) transkrypcji, tj. automatycznego przepisania, bez dodatkowych działań wyjaśniających stan faktyczny, do polskiego rejestru stanu cywilnego (aktu urodzenia) danych jednej z dwóch kobiet wpisanych do zagranicznego systemu rejestracji. W szczególności nie można by zaakceptować rozwiązania polegającego na tym, że jeżeli o taką transkrypcję wnosi obywatelka polska wpisana za granicą jako jedna $\mathrm{z}$ - dwóch w obcym rozumieniu - matek, to należy dokonać transkrypcji aktu urodzenia z jej danymi. Takie automatyczne działanie naruszałoby podstawową zasadę polskiego porządku prawnego, jaką jest macierzyństwo kobiety, która dziecko urodziła. Tym samym groziłoby to naruszeniem art. 105 ust. 1-3 i art. 107 p.a.s.c. W obcych systemach prawnych oraz systemach rejestracji obywatelka (obywatel) polski może być bowiem wpisana jako jedna z dwóch „matek” („ojców”) nie z uwagi na naturalne (biologiczne) pochodzenie dziecka, ale na skutek domniemania pochodzenia od drugiej kobiety (drugiego mężczyzny), która (który) z matką rodzicielką (ojcem) pozostaje pod rządami obcego prawa w związku małżeńskim, w tym na skutek nabycia statusu rodzica drogą umowy z tzw. matką zastępczą. Stąd w razie akceptacji rozwiązania polegającego na częściowej transkrypcji potrzebne byłoby uregulowanie takich sytuacji szczególnych.

Wątpliwości natury jurydycznej budziłby też postulat rozwiązania omawianego problemu przez wprowadzenie do ustawy możliwości odnotowywania w formie przypisku (art. 25 ust. 1 p.a.s.c.) danych drugiej osoby tej samej płci, która za granicą została zarejestrowana zamiast ojca dziecka. Dokonywanie takiego przypisku w powiązaniu $z$ transkrypcją do aktu urodzenia danych pierwszej osoby tej samej płci oceniane łącznie, naruszałoby krajowy porządek prawny. W istocie następuje bowiem przeniesienie do polskiego rejestru całości treści zagranicznej rejestracji (jako akt urodzenia i przypisek), mimo że częściowo jej treść (tj. prawne pochodzenie dziecka od dwóch osób tej samej płci) jest sprzeczna z podstawowymi zasadami polskiego porządku praw- 
nego. Brak możliwości takiego przeniesienia treści zagranicznej rejestracji wynika wprost $\mathrm{z}$ art. 108 ust. 2 p.a.s.c., w którego świetle kierownik może dołączyć wzmiankę dodatkową do aktu stanu cywilnego lub zamieścić przypisek przy tym akcie na podstawie innego dokumentu pochodzącego od organu państwa obcego, jeżeli nie jest to sprzeczne z podstawowymi zasadami porządku prawnego Rzeczypospolitej Polskiej.

Poza tym „adnotacja” w polskim rejestrze poza właściwym aktem urodzenia rozumianym ściśle to też część krajowej rejestracji sensu largo. Ponadto trzeba mieć na względzie, że taka - wątpliwa z perspektywy krajowych zasad prawa osobowego i rodzinnego - treść już w nim zostanie na przyszłość, a jej praktyczne znaczenie może w dalszym orzecznictwie ewoluować (np. prowokować postulaty przyznania pełnych skutków dla całego obrotu prawnego, jakie wynikają dla właściwej treści aktu z art. 3 p.a.s.c.). Taka tzw. częściowa (w istocie: powielenie całościowe obcej treści $\mathrm{z}$ modyfikacją formalną) transkrypcja $\mathrm{z}$ adnotacją w rejestrze drugiego $\mathrm{z}$ „rodziców” to de facto nie transkrypcja częściowa (w znaczeniu - połówkowa), tylko całościowa zmodyfikowana, ponieważ dane osobowe „drugiej matki” też zostają przepisane.

Dodatkowo trzeba mieć na względzie, że przypisek zawiera informacje o innych aktach stanu cywilnego dotyczących tej samej osoby oraz informacje wpływające na stan cywilny tej osoby. Tym samym dotyczy on dokumentowania szeroko rozumianej problematyki stanu cywilnego, a po drugie - przede wszystkim jest on częścią składową polskiego systemu rejestracji stanu cywilnego. Informacja wprowadzana do rejestru $\mathrm{w}$ formie przypisku jest zamieszczana przy akcie stanu cywilnego. Polski system rejestracji stanu cywilnego, postrzegany całościowo, musi być konsekwencją podstawowych zasad polskiego porządku prawnego, w tym zasad ustrojowych (art. 18 Konstytucji). Nazwę „akty stanu cywilnego" trzeba bowiem w tym kontekście rozumieć jako „polską rejestrację stanu cywilnego”, a nie wyłącznie jako akty urodzenia, małżeństwa lub zgonu, które zakresu przedmiotowego tejże rejestracji nie wyczerpują ${ }^{59}$.

59 Na temat prawnego ujęcia macierzyństwa i ojcostwa, które składają się na pochodzenie dziecka - zob. T. Smyczyński (red.), System Prawa Prywatnego, t. 12, dz.cyt., s. 8-18, 93-229.

\section{Załatwianie spraw o wydanie dowodu} tożsamości dziecka bez potrzeby naruszenia zasad krajowej rejestracji stanu cywilnego

Trudność dowodowa w wykazaniu przesłanki pochodzenia dziecka od obywatela polskiego, która to przesłanka rzutuje na nabycie przez nie obywatelstwa potrzebnego do uzyskania dowodu tożsamości, wynika co prawda z przepisów ustawy Prawo o aktach stanu cywilnego (ust. 5 art. 104 p.a.s.c.), zamieszczonych w niej w sąsiedztwie przepisów o transkrypcji zagranicznych aktów (ust. 1-3 art. 104 prawa o a.s.c.). Jednak $\mathrm{w}$ istocie nie dotyczy ona problematyki transkrypcji zagranicznych aktów jako takiej. Wynika de facto $\mathrm{z}$ wymagań dowodowych w sprawie o wydanie paszportu lub dowodu osobistego, która to sprawa nie była przedmiotem postępowania, w którym zapadł omawiany wyrok. Zgodnie z art. 104 ust. 5 prawa o a.s.c. transkrypcja jest obligatoryjna, jeżeli obywatel polski, którego dotyczy zagraniczny dokument stanu cywilnego, ubiega się o polski dokument tożsamości lub nadanie numeru PESEL. Gdyby tego przepisu nie było, w tych postępowaniach szczególnych okoliczność pochodzenia dziecka od polskiego obywatela (czyli macierzyństwa lub ojcostwa) można by wykazywać też drogą inną niż transkrypcja zagranicznego aktu stanu cywilnego. Praktyczne niedogodności, które NSA chciał wyrokiem z 10 października 2018 r. wyeliminować, nie należą więc do sprawy i postępowania o transkrypcję, ale do postępowań w sprawach, które wymienia art. 104 ust. 5 p.a.s.c. Załatwianie tych spraw jest regulowane w innych aktach normatywnych, a przede wszystkim są one przedmiotem innych postępowań administracyjnych. Pojęcie sprawy administracyjnej (sądowoadministracyjnej) jest wyznaczone pojęciem stosunku administracyjnoprawnego, a ta sprawa, którą Sąd chciał pozytywnie załatwić (wydanie dowodu tożsamości), powinna zostać załatwiona $\mathrm{w}$ innym postępowaniu.

Można stanąć na stanowisku, że już po wydaniu wyroku NSA z 10 października 2018 r. zmienił się nieco kontekst normatywny rozstrzyganej sprawy. NSA w sentencji kolejnego (ze spraw na wniosek „rodzica jednopłciowego" w 2018 r.) wyroku z 30 października $2018 \mathrm{r}^{60}$ stwierdził w istocie, że ewentualne problemy

60 II OSK 1868/16. 
ze stwierdzeniem obywatelstwa (co można by odnieść odpowiednio do wydania dowodu tożsamości) mogą zostać wyeliminowane w szczegółowych postępowaniach w tych sprawach. Wobec faktyczej możliwości załatwienia spraw dzieci polskich obywateli nie jest konieczne - nieproporcjonalne - zmienianie podstawowych zasad prowadzenia aktów urodzenia oraz rozumienia rodzicielstwa (pochodzenia dziecka) w polskim porządku prawnym. Nie jest w takim razie konieczne w szczególności zmienianie ogólnych zasad polskiej rejestracji stanu cywilnego w kierunku rozwiązań przyjmowanych w niektórych tylko obcych systemach prawnych, do czego w praktyce mógłby prowadzić wyrok NSA z 10 października $2018 \mathrm{r}$.

Można by obecnie prezentować stanowisko, że powody (kontekst normatywny), dla których NSA przyjął w wyroku z 10 października 2018 r. określoną wykładnię prawa o aktach stanu cywilnego, się zdezaktualizowały. Dla ułatwienia określenia statusu osobowego dzieci pochodzących od polskich obywateli można wykorzystać obecnie - wspomnianą na wstępie - uchwałę Izby Cywilnej SN z 20 listopada 2012 r. oraz zmieniony kontekst normatywny po wyroku NSA z 30 października 2018 r., wydanym nie na tle postępowania o transkrypcję, ale w szczegółowej sprawie administracyjnej.

NSA w tym ostatnim orzeczeniu wskazał, że „Dla statusu prawnego dziecka, w tym możliwości potwierdzenia posiadania polskiego obywatelstwa w oparciu o art. 4 ustawy z 1962 r., nie ma znaczenia to, czy urodziła je matka zastępcza, ale to, że rodzi się istota ludzka obdarzona przyrodzoną i niezbywalną godnością, która ma prawo do obywatelstwa, jeśli jedno z rodziców jest polskim obywatelem". Teza ta jest oczywista, z tym że pojęcie „rodzice” trzeba oczywiście traktować jako pojęcie prawne związane z filiacją i oceniane z perspektywy forum (o czym była mowa wyżej na tle podstawowych zasad prawa krajowego), a nie jako jakiekolwiek rozumienie (np. dotyczące faktycznej osobistej styczności z dzieckiem i wychowywania go albo prawne fikcje pochodzenia dziecka $\mathrm{w}$ prawie obcym, których nie uznaje lex fori ${ }^{61}$. Z obu

61 Stąd na krytykę zasługuje następujący fragment uzasadnienia tego orzeczenia „(..) [Z]agadnienie nabycia obywatelstwa podlega wyłącznie reżimowi publicznoprawnemu. orzeczeń można by bowiem wywodzić możliwość udowodnienia pochodzenia dziecka od polskiego obywatela bez konieczności transkrypcji. Te możliwości dezaktualizują - ocenione wyżej jako nieproporcjonalne - konieczność dokonania wpisu obcej treści do polskiego rejestru stanu cywilnego w trybie art. $104 \mathrm{i}$ in. p.a.s.c.

Mając na względzie ogólną tezę zawartą w uchwale NSA z 2 grudnia 2019 r. oraz możliwe sposoby załatwienia spraw szczegółowych podane w uzasadnieniu tej uchwały, można by nawet postulować, by w postępowaniach szczególnych (o stwierdzenie obywatelstwa, o wydanie dowodu tożsamości, o nadanie PESEL) organy administracji - idąc za uchwałą SN z 20 listopada 2012 r., nie stymulując żądań odejścia od podstawowych zasad rejestracji stanu cywilnego w Polsce - przyjmowały, że zagraniczny akt stanu cywilnego może służyć bezpośrednio jako dowód pochodzenia dziecka od polskiego obywatela. Sprawi to, że żądanie - niemożliwej w niektórych wypadkach - transkrypcji nie będzie konieczne. Oczywiście zagraniczny dokument nie może być dowodem na to, że dziecko pochodzi od drugiej osoby tej samej płci, ale to osobne zagadnienie. Przyjęcie proponowanej wykładni spowodowałoby, że i bez zmiany przepisów polski obywatel, który jest matką lub ojcem dziecka, mógłby w praktyce w miarę łatwo wykazać, że dziecko od niego pochodzi, a tym samym bez większych trudności praktycznych korzystałoby ono z uprawnień przysługujących polskiemu obywatelowi. Ewentualne problemy dowodowe mogłyby powstać w razie braku klarownej informacji w przedkładanym zagranicznym dokumencie, od kogo z dwóch odnotowanych w nim

Nie będą miały zastosowania w sprawie normy prawnorodzinne, które wskazują na sposoby potwierdzenia biologicznego pokrewieństwa pomiędzy dzieckiem a jego rodzicami. W sprawie nie będzie miała też zastosowania, wyrażona w art. 7 ust. 1 ustawy z dnia 4 lutego 2011 r. Prawo prywatne międzynarodowe (Dz.U. nr 80, poz. 432 ze zm.), klauzula porządku publicznego". Notabene jest on wewnętrznie sprzeczny z - poprawnym na tle polskiego stanu prawnego twierdzeniem w innym fragmencie uzasadnienia: „Sąd bierze przy tym pod uwagę, że polskie przepisy nie przewidują uznania, jako rodziców, dwóch osób tej samej płci, jak to uczyniono w amerykańskim akcie urodzenia dziecka”. 
osób tej samej płci dziecko rzeczywiście pochodzi ${ }^{62}$. Informację tę można jednak w postępowaniu uzupełnić przy wykorzystaniu innych zagranicznych dokumentów (np. na temat faktu urodzenia dziecka przez kobietę albo potwierdzenia przekazania tzw. surrogate mother materiału genetycznego przez danego mężczyznę będącego polskim obywatelem). Pomi- bowiem sposobem na naruszenie podstawowych zasad porządku prawnego państwa prowadzącego rejestr ${ }^{63}$.

\section{Uwagi końcowe}

Bieżące orzecznictwo administracyjne i sądowoadminstracyjne zasługują na pozytywną ocenę. Podkreślić trzeba przy tym prawnicze kompetencje kierow-

\section{Bieżące orzecznictwo administracyjne}

i sądowoadministracyjne zasługują na

pozytywną ocenę. Podkreślić trzeba prawnicze

kompetencje kierowników urzędów stanu

cywilnego, którym przyszło się zmierzyć

ze skomplikowanymi jurydycznie sprawami.

nięcie ustalenia tej ostatniej okoliczności, tj. pochodzenia dziecka, zgodnie z podstawowymi zasadami Kodeksu rodzinnego i opiekuńczego (właściwego na tle art. 55 p.p.m.) jest konieczne w szczególności celem zabezpieczenia polskiego porządku prawnego przed nieakceptowanymi z perspektywy polskiego ordre public - skutkami obcego prawa lub orzeczenia (np. przyjmującego domniemanie pochodzenia dziecka od drugiej osoby tej samej płci, która pozostaje z matką dziecka w rejestrowanym związku partnerskim, albo od drugiego mężczyzny, który wraz z ojcem dziecka nabył podobny stan cywilny w drodze kontraktu z surrogate mother). Tryb transkrypcji nie może być

62 Na marginesie warto zauważyć, że to prawo obce i państwo, które przewiduje nietypowe rozwiązania prawne, powinno troszczyć się, by podmioty tychże rozwiązań mogły w jakiś sposób (choćby częściowy) z nich skorzystać w innym państwie, którego prawo rodzinne może się różnić (np. w Polsce). Mogłoby to polegać na wystawianiu na tyle szczegółowych dokumentów związanych z pochodzeniem dziecka (np. adnotacja, że to ona je urodziła), żeby można było za granicą sprawnie udowodnić, że określone dziecko pochodzi biologicznie od określonej kobiety będącej obywatelką innego państwa. ników urzędów stanu cywilnego, którym przyszło się zmierzyć ze skomplikowanymi jurydycznie sprawami. Przekonują uzasadnienia uchwały z 2 grudnia 2019 r., wyroku NSA z 20 czerwca 2018 r. i - powołanego w nim - wcześniejszego orzecznictwa (w tym wyroku

63 Zob. więcej A. Czajkowska, Postępowanie urzędów stanu cywilnego w przypadkach, gdy fakt urodzenia, malżeństwa lub zgonu nastąpił za granica (w:) Obrót prawny z zagranica w sprawach stanu cywilnego, Lublin 1997, s. 56-62; P. Kasprzyk, Sporzadzanie aktów stanu cywilnego na podstawie dokumentów zagranicznych. Uwagi na tle art. 73 ust. 1 ustawy Prawo o aktach stanu cywilnego, „Roczniki Nauk Prawnych” 2010, t. 20, nr 2, s. 215-245; P. Wypych, Zakres badania obcego aktu $w$ ramach postępowania transkrypcyjnego, „Niezbędnik USC. Forum Pracowników Urzędów Stanu Cywilnego przy Małopolskim Instytucie Samorządu Terytorialnego i Administracji” 2014, nr 1, s. 6-7; K. Gładych, Wpisanie zagranicznego aktu stanu cywilnego do rejestru stanu cywilnego, „Technika i USC” 2015, nr 2-3, s. 29-32 i cyt. tam literatura; P. Kasprzyk, Rejestracja zdarzenia majacego miejsce za granic a transkrypcja zagranicznych dokumentów stanu cywilnego, „Metryka” 2016, nr 1, s. 147-159. 
NSA z 17 grudnia 2014 r. $^{64}$ ). Podstawowe zasady prawa polskiego, $\mathrm{w}$ tym rozumienie stanu cywilnego oraz zasady filiacji, skutkują brakiem możliwości transkrypcji kobiety jako „ojca” lub mężczyzny jako „matki”. Państwo dokonujące rejestracji stanu cywilnego, na przykład Polska, może (a nawet musi) dbać o to, by system ten był kompatybilny z podstawowymi zasadami ustrojowymi i prawa rodzinnego forum ${ }^{65}$, w szczególności jeżeli krajowe akta mają daleko idące skutki (art. 3 p.a.s.c.), a załatwienie poszczególnych spraw polskiego obywatela możliwe jest też bez dokonywania transkrypcji obcych dokumentów.

Brak możności przeniesienia do polskiego rejestru stanu cywilnego z obcego dokumentu treści niezgodnej z podstawowymi zasadami prawa krajowego jest uzasadniony w szczególności koniecznością ochrony podstawowych zasad polskiego porządku prawnego (legis fori), które nie uległy zmianie w ostatnich latach, a ponadto są zakorzenione konstytucyjnie. Argumentacja zawarta w uzasadnieniach wyroków NSA z 17 grudnia 2014 r. oraz z 20 czerwca 2018 r. zasługuje na aprobatę i - inaczej niż to przyjął WSA w Poznaniu w wyroku z 5 kwietnia 2018 r. - jest nadal aktualna wobec braku zmiany stanu normatywnego w Polsce. Do zmiany mógłby natomiast de facto doprowadzić (nad)aktywizm sędziowski zaprezentowany w krytykowanych wyżej uzasadnieniach. W szczególności aktualne pozostają tezy uzasadnień wyroków NSA z 17 grudnia 2014 r. oraz z 20 czerwca 2018 r. na temat polskich ustrojowych zasad konstytucyjnych oraz

64 II OSK 1298/13.

65 Zasady dotyczące rodzicielstwa i dziecka ustrojodawca wysunął na czoło Konstytucji RP z 1997 r., a art. 18 został wpisany w treść działu I pt. Rzeczpospolita, który określa podstawy ustroju Polski. Na temat konstytucyjnego ujęcia podstawowych zagadnień prawa rodzinnego, $w$ tym rodzicielstwa - zob. W. Borysiak (w:) M. Safjan, L. Bosek (red.), Konstytucja RP. Art. 1-86. Komentarz, dz. cyt., s. 478 i n. Zob. też M. Nazar, Niektóre zagadnienia małżeństwa i rodziny w świetle unormowań Konstytucji RP z dnia 2 kwietnia 1997 r., „Rejent” 1997, nr 5, s. 109-110; T. Smyczyński, Rodzina i prawo rodzinne w świetle nowej Konstytucji RP, „Państwo i Prawo” 1997, nr 11, s. 188; S. Kalus, Konstytucyjne źródła zasad polskiego prawa rodzinnego (w:) I. Bogucka, Z. Tobor (red.), Prawo a wartości. Księga jubileuszowa Profesora Józefa Nowackiego, Kraków 2003, s. 105-106. podstawowych zasad polskiego prawa rodzinnego, a ponadto odnośnie do odrębności ogólnego postępowania (sprawy) o transkrypcję oraz szczególnego postępowania (sprawy) np. o wydanie dowodu tożsamości lub o potwierdzenie obywatelstwa. Aktualność zachowują także dokładne uwagi zawarte w uzasadnieniach tych wyroków na temat nietrafności powoływanych obficie przez wnioskodawców argumentów mówiących o naruszeniu przez polskie organy prawa międzynarodowego i prawa Unii Europejskiej. Do tych ostatnich warto dodać, że podejście zaprezentowane w krytykowanych orzeczeniach może co prawda ułatwić załatwienie sprawy o wydanie dziecku dowodu osobistego, ale jednocześnie oznaczać będzie zburzenie „od środka” polskiego systemu rejestracji stanu cywilnego ${ }^{66}$, a nawet naruszyć może fundamenty prawa ustrojowego i rodzinnego w polskim porządku prawnym.

Dla klaryfikacji stanu normatywnego rozważać można by również zmianę ust. 5 art. 104 p.a.s.c. polegającą na rezygnacji z obowiązku transkrypcji zagranicznego aktu stanu cywilnego, jeżeli polski obywatel ubiega się o polski dokument tożsamości lub nadanie numeru PESEL. Na tle poprzedniej ustawy dokonywanie transkrypcji było fakultatywne i takie rozwiązanie w obecnej rzeczywistości, w której pojawiły się zagraniczne dokumenty o niespodziewanej treści, można widzieć jako optymalne. Celem wykazania obywatelstwa, bazującego na macierzyństwie lub ojcostwie zgodnie z zasadami polskiego prawa rodzinnego, można by wówczas nadal dokonywać transkrypcji zagranicznego aktu, o ile jego treść nadaje się do przeniesienia w tym trybie. W sytuacjach, w których tryb transkrypcji nie może znaleźć zastosowania - na przykład w stanie faktycznym u podstawy wyroku NSA z 10 października 2018 r. - wykazanie pochodzenia dziecka od polskiego obywatela mogłoby nastąpić też innymi środkami, w tym w prostym trybie opisanym w art. 1138 k.p.c. Warto mieć przy tym na względzie, że w uzasadnieniu nowej ustawy p.a.s.c. wskazano, że: „Bezsprzecznie moc dowodowa zagranicznych

66 Tak M. Wojewoda, Transkrypcja zagranicznego dokumentu stanu cywilnego..., dz. cyt., s. 53 i n.; tenże, Transkrypcja aktu urodzenia dziecka, które zostało uznane za granica, dz. cyt. s. $347-350$. 
aktów stanu cywilnego nie zależy od ich zarejestrowania w polskim systemie rejestracji stanu cywilnego, a posiadanie takiego dokumentu jest wystarczającym potwierdzeniem urodzenia" ${ }^{37}$.

Mając na względzie Uchwałę siedmiu sędziów NSA z 2 grudnia 2019 r., wydaje się, że nawet i bez nowelizacji p.a.s.c., a przy wykorzystaniu wykładni art. 1138 k.p.c. przyjętej przez SN w uchwale z dnia 20 listopada 2012 r., możliwe jest już obecnie odejście
Państwa, w których systemach prawnych wprowadzono daleko idące zmiany (np. odejście od rozumienia prawnego rodzicielstwa jako sumy macierzyństwa i ojcostwa, które jest fundamentem prawa polskiego) nie mogą i nie „wymagają" od pozostałych (tu nawet większości państw na świecie, przy czym proporcja nie jest istotna, lecz lex fori), by te ostatnie uznawały, nawet pośrednio, takie zmodyfikowane zagranicą ujęcie. Logicznie rzecz biorąc, postulat uznawania skutków

\section{Dla klaryfikacji stanu normatywnego warto} rozważyć rezygnację z obowiązku transkrypcji zagranicznego aktu stanu cywilnego, jeżeli polski obywatel ubiega się o polski dokument tożsamości lub nadanie numeru PESEL.

od praktyki wymagania wcześniejszej transkrypcji przez postępowaniem o wydanie dowodu tożsamości, z uwagi na przyjęcie istnienia aktu (tj. części zagranicznej rejestracji mówiącej o pochodzeniu dziecka od kobiety, która je urodziła) w rozumieniu art. 3 p.a.s.c. W uzasadnieniu projektu p.a.s.c. - prócz sygnalizowanych wyżej: dodania czterech przepisów wyrażających klauzule porządku publicznego oraz wyjaśnienia, że wprowadzenie obligatoryjnej transkrypcji w kilku sytuacjach było uzasadnione specyfiką systemu teleinformatycznego i dążeniem do uzupełniania danych osobowych potrzebnych do nadania PESEL w postępowaniu o transkrypcję, a nie w postępowaniu np. o wydanie dowodu tożsamości - zauważono, że:

„Polska nie będzie jedynym krajem w Europie, w którym transkrypcja zagranicznego aktu stanu cywilnego jest obowiązkowa. Obligatoryjną transkrypcję wprowadzono m.in. w Szwajcarii czy Słowacji”. Z powyższego wynika, że wprowadzone rozwiązanie prawne nie jest powszechne.

67 Zob. więcej: http://www.sejm.gov.pl/sejm7.nsf/druk. xsp?nr=2620, s. 51 (dostęp 24.01.2020). zastosowania jakiegokolwiek (każdego) obcego prawa nie byłby możliwy do realizacji, ponieważ poszczególne systemy prawne (prawodawstwa) na świecie niekiedy są ze sobą sprzeczne (np. odnośnie do tożsamości małżeństwa lub - w istocie faktu - filiacji, czyli rodzicielstwa jako macierzyństwa powiązanego z ojcostwem) i nie da się ich wszystkich pogodzić. Stąd kluczowe znaczenie na danym terytorium muszą mieć podstawowe zasady prawa osobowego i rodzinnego państwa, które prowadzi dany rejestr. Można nawet bronić twierdzenia, że stąd część zarzutów wyrażonych w toku postępowań przez wnioskodawców i Rzecznika Praw Obywatelskich powinno zostać skierowanych nie przeciwko prawu polskiemu oraz polskim organom i sądom, ale przeciw np. państwu wprowadzającemu nietypowe rozwiązania dotyczące pochodzenia dziecka (np. organizującemu procedury surrogate motherhood). Z perspektywy zagranicznej, która jest przedmiotem niniejszych uwag, to właśnie państwo, przez nieinformowanie w dokumentach dotyczących urodzenia dziecka o jego matce, de facto utrudnia wywołanie niektórych skutków prawnych w Polsce i w licznych państwach o podobnym prawie 
(np. udowodnienia na potrzeby załatwienia sprawy administracyjnej, który z dwóch mężczyzn nabywających pod rządami obcego prawa status „rodziców” jest rzeczywiście ojcem dziecka w rozumieniu prawa państwa żądanej rejestracji) ${ }^{68}$.

\section{Bibliografia}

Borysiak W. (w:) M. Safjan, L. Bosek (red.), Konstytucja RP. Art. 1-86. Komentarz, Warszawa 2016.

Czajkowska A. (w:) I. Basior, A. Czajkowska, D. Sorbian (red.), Prawo o aktach stanu cywilnego z komentarzem. Przepisy wykonawcze i związkowe oraz wzory dokumentów, Warszawa 2015

Czajkowska A., Postępowanie urzędów stanu cywilnego w przypadkach, gdy fakt urodzenia, matżeństwa lub zgonu nastąpit za granica (w:) Obrót prawny z zagranica w sprawach stanu cywilnego, Lublin 1997.

Dobkowski J., Preponderancja aktów stanu cywilnego, „Metryka” 2011, nr 2, s. 15-32, http://metryka.info/wp-content/uploads/2016/06/2_dobkowski.pdf, 24.01.2020.

Figura-Góralczyk E., Uwagi dotyczące orzeczenia Niemieckiego Sądu Zwiazkowego z 20 marca 2019 (BGH XII ZB 530/17) (w:) P. Mostowik (red.), Fundamentalne prawne problemy surrogate motherhood. Perspektywa krajowa, Warszawa 2019.

Gładych K., Wpisanie zagranicznego aktu stanu cywilnego do rejestru stanu cywilnego, „Technika i USC” 2015, nr 2-3.

Kalus S., Konstytucyjne źródła zasad polskiego prawa rodzinnego (w:) I. Bogucka, Z. Tobor (red.), Prawo a wartości. Księga jubileuszowa Profesora Józefa Nowackiego, Kraków 2003.

Kasprzyk P. (red.), Podręcznik urzędnika stanu cywilnego, t. 2: Obrót prawny z zagranica $w$ zakresie rejestracji stanu cywilnego, Lublin 2019.

Kasprzyk P., Rejestracja zdarzenia mającego miejsce za granic a transkrypcja zagranicznych dokumentów stanu cywilnego, „Metryka” 2016, nr 1.

Kasprzyk P., Sporządzanie aktów stanu cywilnego na podstawie dokumentów zagranicznych. Uwagi na tle art. 73 ust. 1 ustawy Prawo o aktach stanu cywilnego, „Roczniki Nauk Prawnych” 2010, t. 20, nr 2.

Kownacki R., Ingerencja Karty Praw Podstawowych w zakres realizacji przez państwa członkowskie tematów sensytywnych (eutanazja, związki homoseksualne, aborcja) - propagandowy straszak czy realna perspektywa? (w:) A. Wróbel (red.), Karta

68 Zob. więcej P. Mostowik, Problem obywatelstwa dziecka prawdopodobnie pochodzacego od obywatela polskiego niebędącego mężem surrogate mother..., dz. cyt., s. 70 i n.
Praw Podstawowych w europejskim i krajowym porzadku prawnym, Warszawa 2009.

Martinez de Aguirre C., Umowy o międzynarodowe macierzyństwo zastępcze: globalna Opowieść podręcznej? (w:) P. Mostowik (red.), Fundamentalne prawne problemy surrogate motherhood. Perspektywa krajowa, Warszawa 2019.

Michałowska K., Niemajątkowe wartości życia rodzinnego w polskim prawie cywilnym, Warszawa 2017.

Mirocha Ł., Tzw. macierzyństwo zastępcze (surrogacy, Leihmutterschaft) w bieżącym orzecznictwie Europejskiego Trybunału Praw Człowieka w Strasburgu, „Prawo w Działaniu” 2018, t. 34, s. 164, https://iws.gov.pl/wp-content/uploads/2018/08/ IWS-Mirocha-Ł.-Tzw.-macierzyństwo-zastępcze-surrogacy-Leihmutterschaft-w-bieżącym-orzecznictwie-Europejskiego-Trybunału-Praw-Człowieka-w-Strasburgu.pdf, 24.01.2020.

Mostowik P. (red.), Fundamentalne prawne problemy surrogate motherhood. Perspektywa krajowa, Warszawa 2019.

Mostowik P., Kwestia zakresu zastosowania rozporzadzenia UE nr 1191/2016 do zagranicznej rejestracji stanu cywilnego, „Rodzina i Prawo” 2016, nr 37, s. 97 i n., https://ruj.uj.edu.pl/ xmlui/handle/item/37262, 24.01.2020.

Mostowik P., Legislative Activities of European Union versus Fundamental Principles of Paternity and Maternity in Member States, „International Journal of the Jurisprudence of the Family" 2017, t. 8, https://papers.ssrn.com/sol3/papers. cfm?abstract_id=3224049, 24.01.2020.

Mostowik P., Pochodzenie dziecka (w:) M. Pazdan (red.), System Prawa Prywatnego, t. 20C: Prawo prywatne międzynarodowe, Warszawa 2015.

Mostowik P., Problem obywatelstwa dziecka prawdopodobnie pochodzacego od obywatela polskiego niebędącego mężem surrogate mother. Uwagi aprobujace wyroki NSA $z 6$ maja 2015 r. (II OSK 2372/13 I II OSK 2419/13), „Problemy Współczesnego Prawa Międzynarodowego, Europejskiego i Porównawczego" 2018, t. 16.

Mostowik P., Władza rodzicielska w prawie prywatnym międzynarodowym, Kraków 2014.

Nazar M., Niektóre zagadnienia małżeństwa i rodziny wświetle unormowań Konstytucji RP z dnia 2 kwietnia 1997 r., „Rejent” 1997, nr 5.

Pilich M., Mater semper certa est? Kilka uwag o skutkach zagranicznego macierzyństwa zastępczego z perspektywy stosowania klauzuli porządku publicznego, „Problemy Współczesnego Prawa Międzynarodowego, Europejskiego i Porównawczego” 2018, t. 16. 
Przyśliwska-Urbanek E., Aktualne orzecznictwo sądów administracyjnych dotyczace rejestracji pochodzenia dziecka od osób tej samej płci (w:) J. Gołaczyński, W. Popiołek (red.), Kolizyjne i procesowe aspekty prawa rodzinnego, Warszawa 2019.

Smyczyński T. (red.), Konwencja o prawach dziecka. Analiza i wykładnia, Poznań 1999.

Smyczyński T. (red.), System Prawa Prywatnego, t. 12: Prawo rodzinne i opiekuńcze, Warszawa 2011.

Smyczyński T., Rodzina i prawo rodzinne $w$ świetle nowej Konstytucji RP, „Państwo i Prawo” 1997, nr 11.

Wojewoda M., Kolizyjnoprawne aspekty rejestracji stanu cywilnego (w:) M. Pazdan (red.), System Prawa Prywatnego, t. 20C: Prawo prywatne międzynarodowe, Warszawa 2015.

Wojewoda M., Transkrypcja aktu urodzenia dziecka, które zostało uznane za granica, „Kwartalnik Prawa Prywatnego” 2017, nr 2.

Wojewoda M., Transkrypcja zagranicznego dokumentu stanu cywilnego - kilka uwag na temat ewolucji konstrukcji w prawie polskim, „Metryka” 2016, nr 2.

Wypych P., Charakter prawny transkrypcji aktu stanu cywilnego sporzadzonego za granica, „Kwartalnik Prawa Prywatnego" 2003, nr 1.

Wypych P., Zakres badania obcego aktu w ramach postępowania transkrypcyjnego, „Niezbędnik USC. Forum Pracowników Urzędów Stanu Cywilnego przy Małopolskim Instytucie Samorządu Terytorialnego i Administracji” 2014, nr 1.

Wysocka-Bar A., Nabycie polskiego obywatelstwa a urodzenie przez matkę zastępczą. Uwagi na tle wyroków Naczelnego Sądu Administracyjnego $z$ dnia 6 maja 2015 r.: II OSK 2372/13 oraz II OSK 2419/13, „Problemy Współczesnego Prawa Międzynarodowego, Europejskiego i Porównawczego" 2018, t. 16.

\section{Akty prawne}

Konwencja o ochronie dzieci i współpracy w dziedzinie przysposobienia międzynarodowego, sporządzona w Hadze dnia 29 maja 1993 r., Dz.U. 2000 nr 39 poz. 448 ze sprost.

Konwencja o prawach dziecka przyjęta przez Zgromadzenie Ogólne Narodów Zjednoczonych dnia 20 listopada 1989 r., Dz.U. $1991 \mathrm{nr}$ 120, poz. 526 ze zm.

Rozporządzenie Parlamentu Europejskiego i Rady (UE) 2016/1191 z dnia 6 lipca 2016 r. w sprawie promowania swobodnego przepływu obywateli poprzez uproszczenie wymogów dotyczących przedkładania określonych dokumentów urzędowych w Unii Europejskiej i zmieniające Rozporządzenie (UE) nr 1024/2012, Dz.U. UE L nr 200.
Rządowy projekt ustawy - Prawo o aktach stanu cywilnego, Sejm VII kadencji, druk nr 2620, http://www.sejm.gov.pl/sejm7.nsf/ druk.xsp?nr=2620, 24.01.2020.

Traktat o UE, Dz.U. 2004 nr 90 poz. 864/30 ze zm.; wersja skonsolidowana w Dz.U. UE C 2010 nr 83.

Ustawa z dnia 13 lipca 2006 r. o dokumentach paszportowych, t.j. Dz.U. 2018 poz. 1919.

Ustawa z dnia 13 lipca 2006 r. o dokumentach paszportowych; t.j. Dz.U. 2018 poz. 1919.

Ustawa z dnia 17 listopada 1964 r. Kodeks postępowania cywilnego, t.j. Dz.U. 2018 poz. 1360 ze zm.

Ustawa z dnia 2 kwietnia 2009 r. o obywatelstwie polskim, t.j. Dz.U. 2018 poz. 1829.

Ustawa z dnia 29 września 1986 r. Prawo o aktach stanu cywilnego, t.j. Dz.U. 2011 nr 212 poz. 1264 ze zm.

Ustawa z dnia 4 lutego 2011 r. Prawo prywatne międzynarodowe, t.j. Dz.U. 2015 poz. 1792.

Ustawa z dnia 6 sierpnia 2010 r. o dowodach osobistych; t.j. Dz.U. 2017 poz. 1464 ze zm.

\section{Orzecznictwo}

Contribution of Feminist and Human Rights Organizations to the Work of The Hague Conference on Private International Law Regarding Legal Issues Concerning International Surrogacy Conventions ("Parentage/Surrogacyproject"). Comments on Preliminary Document No 3 B of March 2014 and Preliminary Document No 3A of February 2015, https://collectifcorp.files. wordpress.com/2015/01/surrogacy_hcch_feminists_english. pdf, 24.01.2020.

Obwieszczenie Marszałka Sejmu Rzeczypospolitej Polskiej z dnia 9 marca 2017 r. w sprawie ogłoszenia jednolitego tekstu ustawy - Kodeks rodzinny i opiekuńczy, t.j. Dz.U. 2017 poz. 682 ze zm.

Obwieszczenie Marszałka Sejmu Rzeczypospolitej Polskiej z dnia 9 listopada 2018 r. w sprawie ogłoszenia jednolitego tekstu ustawy - Prawo o aktach stanu cywilnego, t.j. Dz.U. 2018 poz. 2224 ze zm.

Uchwała NSA z 2 grudnia 2019 r., II OPS 1/19; http://orzeczenia. nsa.gov.pl/doc/0CB4DBF3D4, 24.01.2020.

Uchwała SN z 20 listopada 2012 r., III CZP 58/12, www.sn.pl/ Sites/orzecznictwo/Orzeczenia2/III\%20CZP\%2058-12.pdf, 24.01.2020.

Uchwała SN z 20 listopada 2012 r., III CZP 58/12, www.sn.pl/ Sites/orzecznictwo/Orzeczenia2/III\%20CZP\%2058-12.pdf, 24.01.2020.

Wyrok ETPC z 15 marca 2012 r., skarga 25951/07; LEX nr 1130706. 
Wyrok ETPC z 24 stycznia 2017 r., skarga nr 25358/12.

Wyrok Naczelnego Sądu Administracyjnego z dnia 28 lutego 2018 r., II OSK 1112/16, LEX nr 2495844.

Wyrok NSA z 10 października 2018 r., II OSK 2552/16, http:// orzeczenia.nsa.gov.pl/doc/013EB55F39, 24.01.2020.

Wyrok NSA z 17 grudnia 2014 r., II OSK 1298/13, http://orzeczenia.nsa.gov.pl/doc/ADA943DFA1, 24.01.2020.

Wyrok NSA z 20 czerwca 2018 r., II OSK 1808/16, LEX nr 2513922, http://orzeczenia.nsa.gov.pl/doc/F1FEC11C03, 24.01.2020.

Wyrok NSA z 30 października 2018 r., II OSK 1868/16, http://www.orzeczenia-nsa.pl/wyrok/ii-osk-1868-16/ obywatelstwo/293ac30.html, 24.01.2020.

Wyrok NSA z 6 maja 2015 r., II OSK 2372/13, http://orzeczenia. nsa.gov.pl/doc/12EBFE1F1E, 24.01.2020.

Wyrok NSA z 6 maja 2015 r., II OSK 2419/13, http://orzeczenia. nsa.gov.pl/doc/A7BCB1D1A8, 24.01.2020.

Wyrok WSA w Krakowie z 10 maja 2016 r., III SA/Kr 1400/15, http://orzeczenia.nsa.gov.pl/doc/431B8D990D, 24.01.2020.

Wyrok WSA w Poznaniu z 5 września 2018 r., II SA/Po 1169/17, http://orzeczenia.nsa.gov.pl/doc/7C7192478E, 24.01.2020.

Wyrok z dnia 1 kwietnia 2008 r., Maruko, C-267/06, EU:C: 2008: 179, pkt 59.
Wyrok z dnia 14 października 2008 r., Grunkini Paul, C-353/06, EU:C: 2008: 559, pkt 16.

Wyrok z dnia 2 października 2003 r., Garcia Avello, C-148/02, EU:C: 2003: 539, pkt 25.

Wyrok z dnia 24 listopada 2016 r., Parris, C-443/15, EU:C: 2016:897, pkt 59.

Wyrok z dnia 5 czerwca 2018 r. w sprawie C-673/16 (sprawa Coman v. Rumunia), http://curia.europa.eu/juris/document/ document.jsf?docid $=202542 \&$ mode $=$ req \&pageIndex $=1 \&$ dir $=\&$ occ $=$ first $\&$ part $=1 \&$ text $=\&$ doclang $=P L \& c i d=301542 \#$ Foot note, 24.01.2020.

Inne

Opinia doradcza z 10 kwietnia 2019 r. dotycząca uznania w prawie krajowym stosunku prawnego rodzic-dziecko między dzieckiem urodzonym w ramach surogacji za granicą a matką intencyjną. Wniosek francuskiego sądu kasacyjnego (wniosek nr P16-2018-001).

Report of 30 November 2015 on the Annual Report on Human Rights and Democracy in the World 2014 and the European Union's policy on the matter, 2015/2229(INI), http:// www.europarl.europa.eu/doceo/document/A-8-2015-0344_ EN.html?redirect, 24.01.2020. 